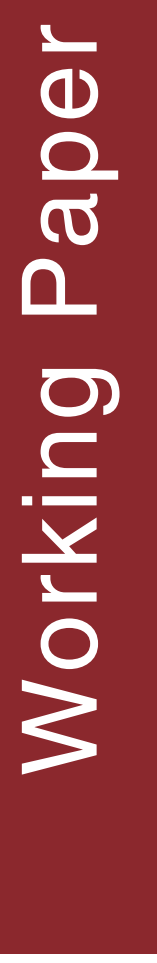

Marine habitats of the Lamu-Kiunga coast: an assessment of biodiversity value, threats and opportunities

Kennedy Osuka, Melita Samoilys, James Mbugua, Jan de Leeuw, David Obura
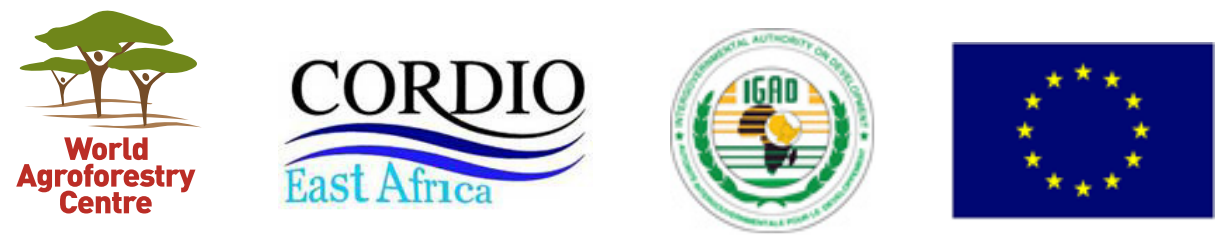


\section{Marine habitats of the Lamu-Kiunga coast: an assessment of biodiversity value, threats and opportunities}

Kennedy Osuka, Melita Samoilys, James Mbugua, Jan de Leeuw, David Obura
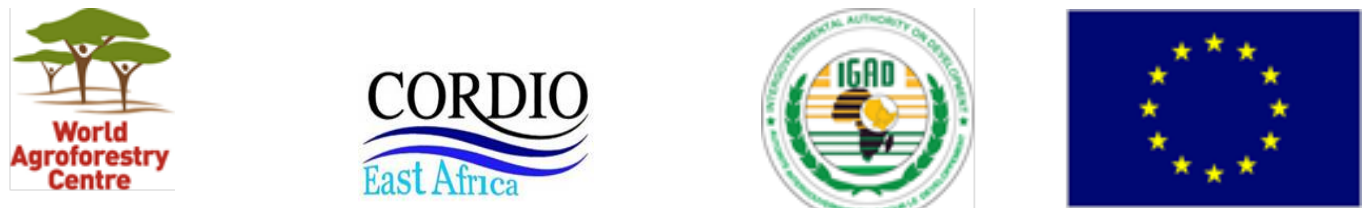
Correct citation: Osuka K, Melita Samoilys M, Mbugua J, de Leeuw J, Obura D. 2016. Marine habitats of the Lamu-Kiunga coast: an assessment of biodiversity value, threats and opportunities. ICRAF Working paper number no. 248 World Agroforestry Centre. DOI: http://dx.doi.org/10.5716/WP16167.PDF

Titles in the Working Paper series aim to disseminate interim results on agroforestry research and practices, and stimulate feedback from the scientific community. Other publication series from the World Agroforestry Centre include: Technical Manuals, Occasional Papers and the Trees for Change Series.

Published by the World Agroforestry Centre

United Nations Avenue

PO Box 30677, GPO 00100

Nairobi, Kenya

Tel: +254 207224000 , via USA +1 6508336645

Email:worldagroforestry@cgiar.org

Website: www.worlagroforestry.org

(C) World Agroforestry Centre 2016

Working Paper No. 248

Photos/illustrations: all photos are appropriately accredited.

The views expressed in this publication are those of the author(s) and not necessarily those of the World Agroforestry Centre.

Articles appearing in this publication may be quoted or reproduced without charge, provided the source is acknowledged.

All images remain the sole property of their source and may not be used for any purpose without written permission from the source. 


\section{About the authors}

Kennedy Osuka is research scientist at CORDIO East Africa. Email: kosuka@cordioea.net

Melita Samoilys is a director, CORDIO East Africa. Email: melita.samoilys@gmail.com

James Mbugua is a research assistant at CORDIO East Africa. Email: jmbugua@cordioea.net

Jan de Leeuw worked as a senior scientist with ICRAF's Eastern and Southern African team. He is currently an ecologist at Baku State University. Email: jan45leeuw@gmail.com

David Obura is the coordinator for CORDIO East Africa. Email: dobura@cordioea.net 


\section{Acknowledgements}

The publication is an outcome of an activity of marine biodiversity assessment, which was commissioned by ICRAF and implemented by CORDIO East Africa. Special gratitude goes to EU through IGAD for funding the activity. CORDIO team also thank all those who contributed to the study by providing the information required for the preparation of this Publication. The authors would also thank Dr. Maarifa Wakumanya, Pwani University, Grace Koech and Josephat Nyongesa for reviewing the manuscript. Finally, the authors would like to thank the ICRAF communication team for proof reading and publishing the working paper. 


\section{Table of Contents}

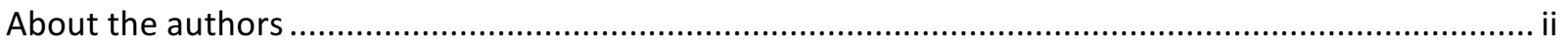

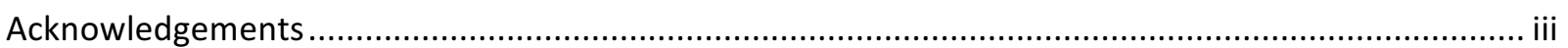

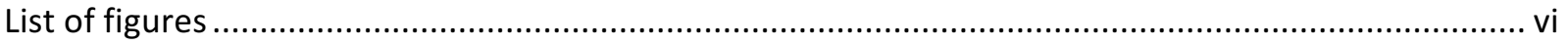

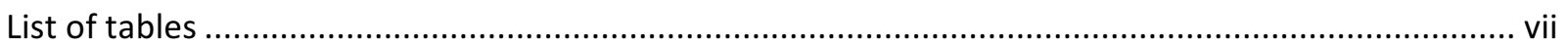

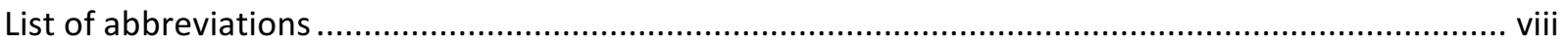

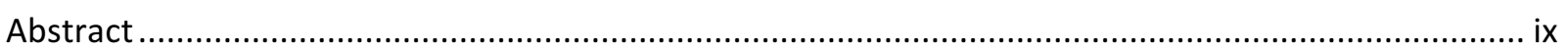

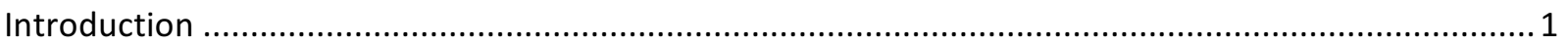

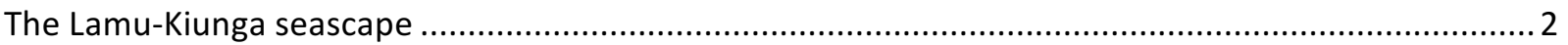

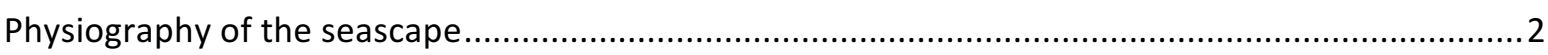

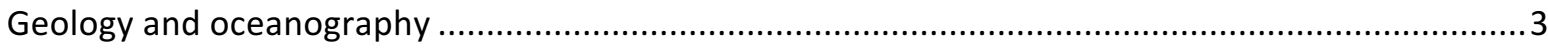

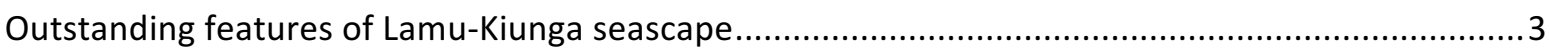

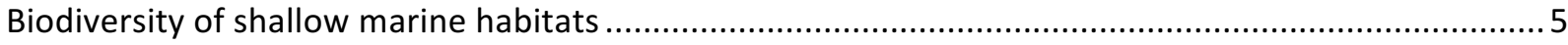

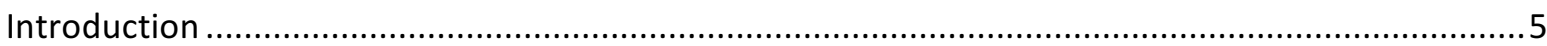

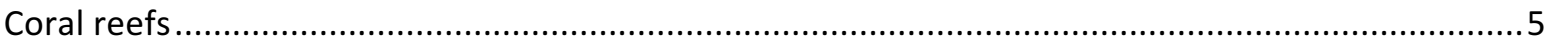

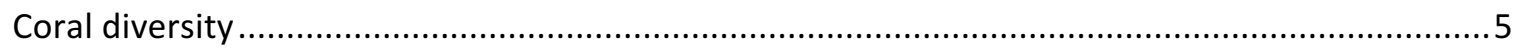

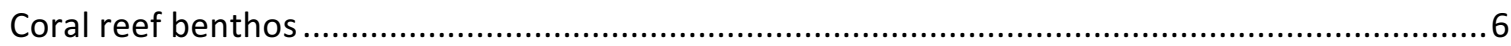

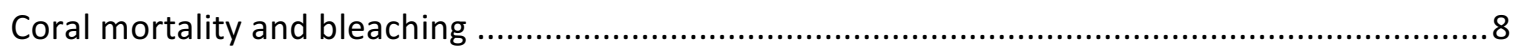

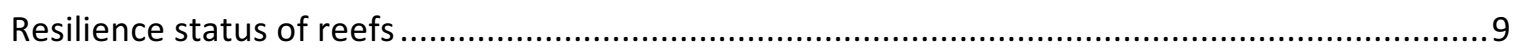

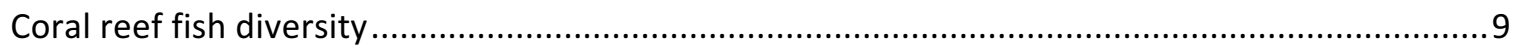

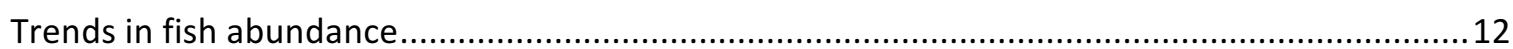

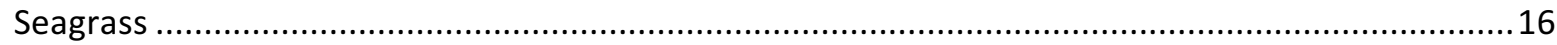

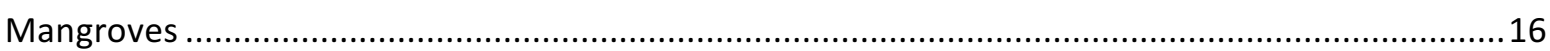

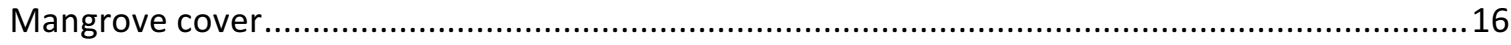

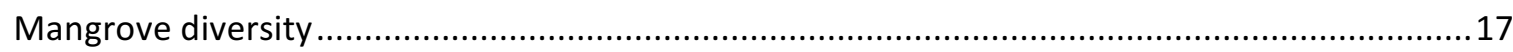

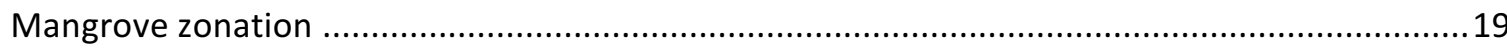

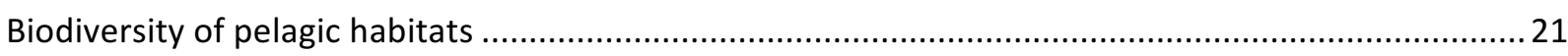

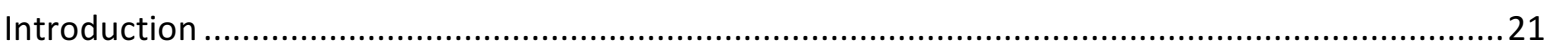

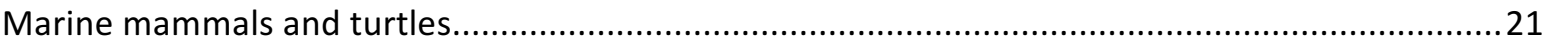

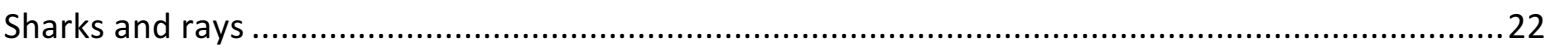

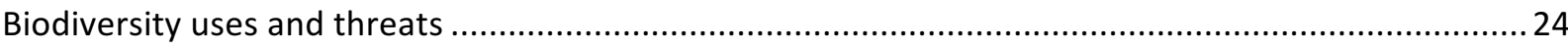

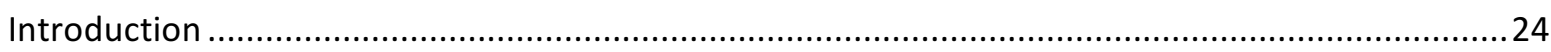

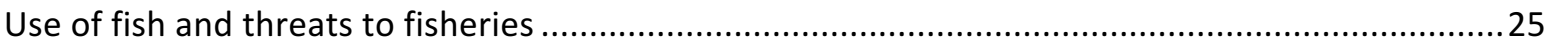

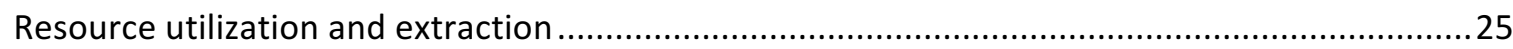

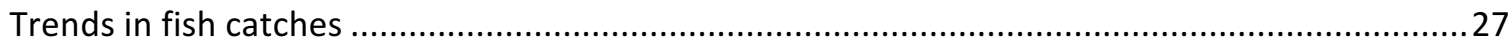

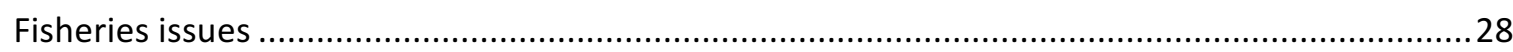

Lamu Port and Lamu-Southern Sudan-Ethiopia Transport Corridor project ................................28

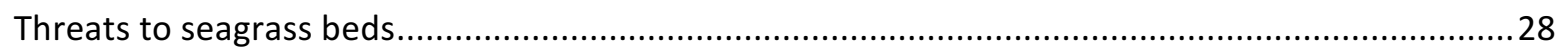

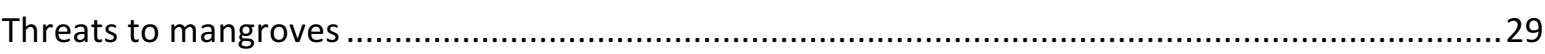

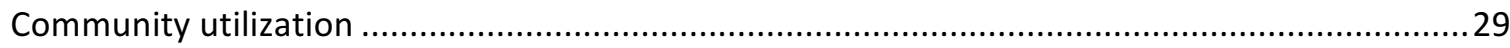




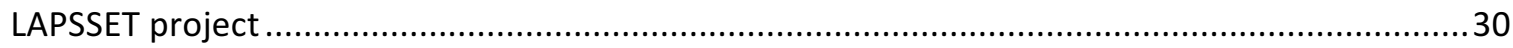

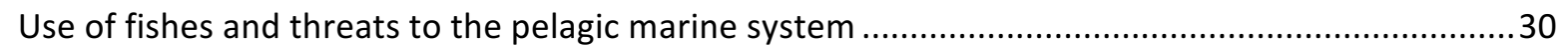

Opportunities for improved management ..................................................................... 31

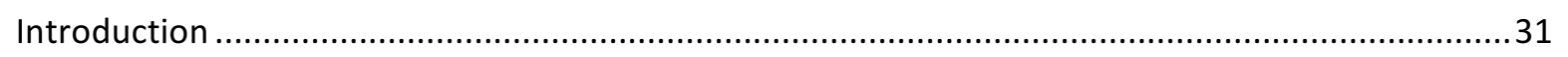

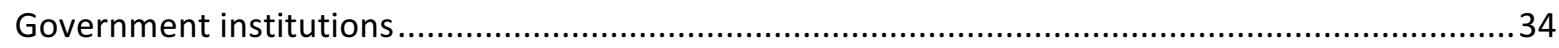

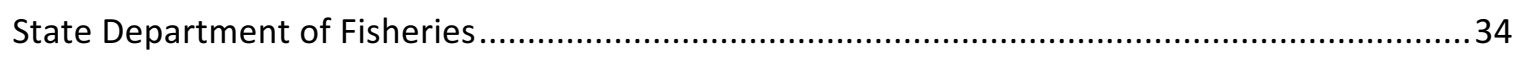

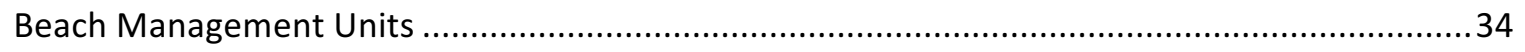

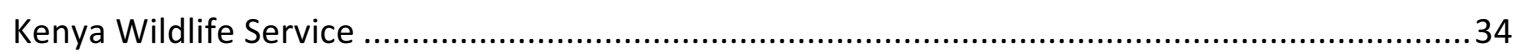

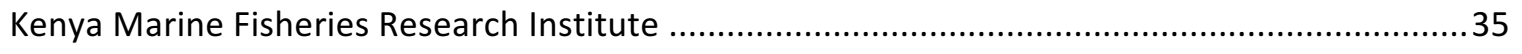

Policy and institutions for management of mangroves .........................................................35

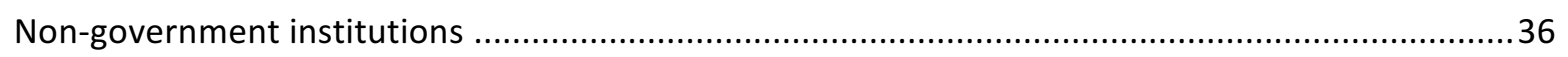

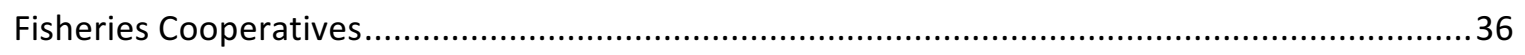

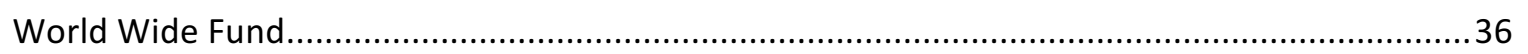

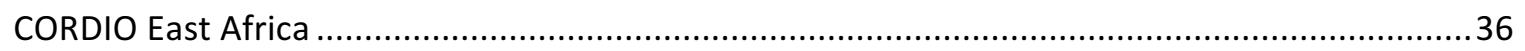

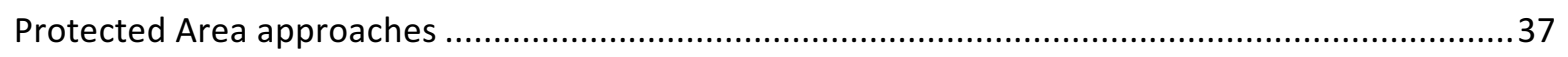

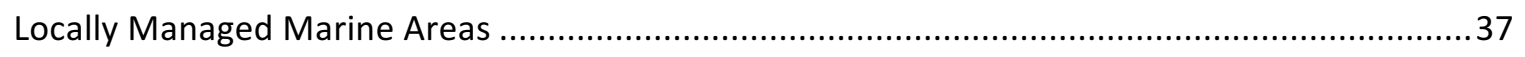

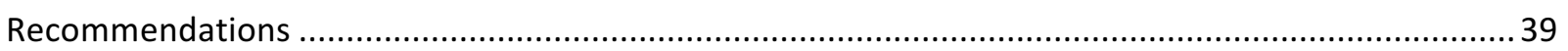

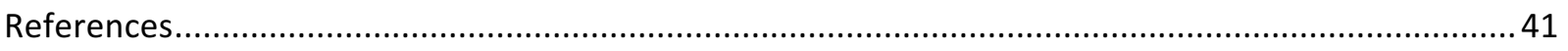

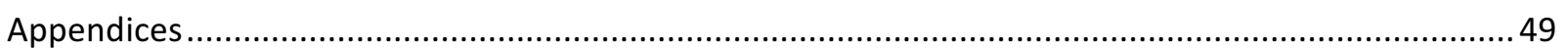

Appendix 1. Coral genera and species list recorded in Pate-Kiunga 2015 .................................49

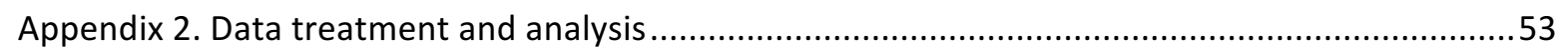

Appendix 3. Fish species list recorded in Pate-Kiunga in 2015 ..................................................54 
Figure 1: Map of coastline showing Kiunga Marine National Reserve and the conservancies..... 2

Figure 2: Spatial extent of coral reefs of the Kenyan coast and the $200 \mathrm{~m}$-depth contour ..................... 3

Figure 3: Change in the cover of benthic variables in the Lamu-Kiunga area ......................................... 7

Figure 4: Map of in-situ coral reef survey sites conducted by CORDIO...............................................

Figure 5: Fish abundance of 11 selected families in Kiunga-Pate seascape ......................................14

Figure 6: Mean density and biomass of fish families surveyed at six sites in Pate Island-Kiunga ..........15

Figure 7: Spatial distribution of mangroves along the Kenyan coast ..............................................17

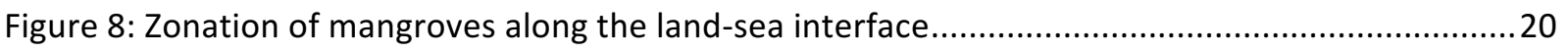

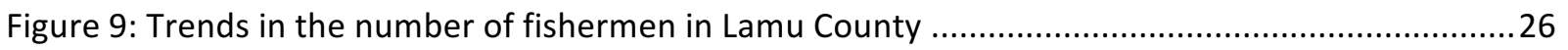

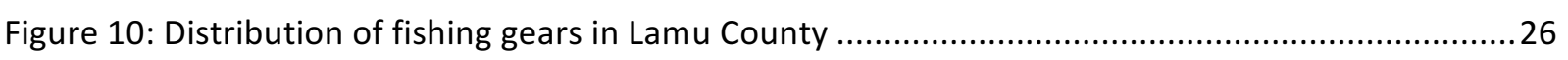

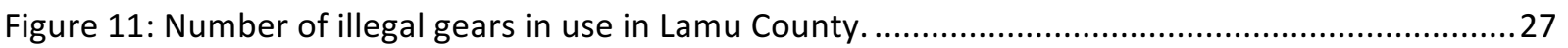

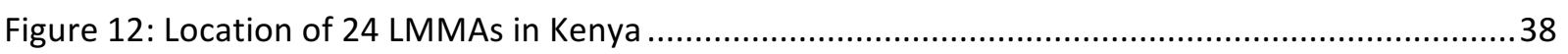




\section{List of tables}

Table 1: Densities of coral adults and recruits sampled in Kiunga Marine National Reserve .8

Table 2: Total number of reef fish species per family per site................................................... 11

Table 3: Coral reef fish diversity index values for Lamu-Kiunga and from other WIO countries ........... 12

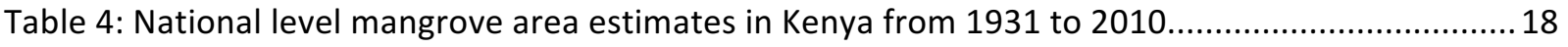

Table 5: Mangrove species of Lamu-Kiunga region................................................................ 19

Table 6: Species distribution and cover within the Kiunga Marine National Reserve.........................19

Table 7: IUCN categories of marine mammals sighted in Pate Island-Kiunga area...........................2 21

Table 8: IUCN categories of sharks and rays fished and sighted in Pate Island-Kiunga area. ..............22

Table 9: Mean catch per unit effort from 2001-2007 of gears used in Lamu County ........................27

Table 10: DPSIR analysis of environmental problems affecting biodiversity in the shallow and pelagic

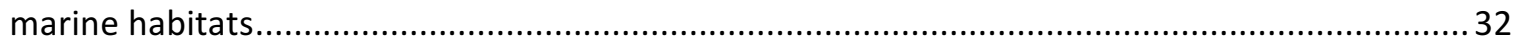

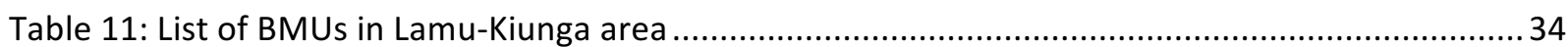

Table 12: Nationally gazetted Marine Protected Areas in Kenya...............................................37 


\section{List of abbreviations}

\begin{tabular}{|c|c|}
\hline BMP & Biodiversity Management Programme \\
\hline BMU & Beach Management Unit \\
\hline CBD & Convention on Biological Biodiversity \\
\hline CFDI & Coral Fish Diversity Index \\
\hline CORDIO & Coastal Oceans Research and Development Indian Ocean \\
\hline CPUE & Catch Per Unit Effort \\
\hline DPSIR & Driving Force-Pressure-State-Impact-Response framework \\
\hline EACC & East Africa Coastal Current \\
\hline EEZ & Exclusive Economic Zone \\
\hline ENSO & El Niño Southern Oscillation \\
\hline EU & European Union \\
\hline FAO & Food and Agriculture Organization of the United Nations \\
\hline GBR & Great Barrier Reef \\
\hline GoK & Government of Kenya \\
\hline ICRAF & World Agroforestry Centre \\
\hline IGAD & Intergovernmental Authority on Development \\
\hline IP & Implementing Partner \\
\hline IUCN & International Union for Conservation of Nature \\
\hline IUU & Illegal Unregulated and Unreported \\
\hline KFS & Kenya Forest Service \\
\hline KMCC & Kiunga Marine Community Conservancy \\
\hline KMFRI & Kenya Marine Fisheries Research Institute \\
\hline KMNR & Kiunga Marine National Reserve \\
\hline KWS & Kenya Wildlife Service \\
\hline LAPSSET & Lamu Port Southern Sudan-Ethiopia Transport \\
\hline LMMAs & Locally Managed Marine Areas \\
\hline MPAs & Marine Protected Areas \\
\hline MSP & Marine Spatial Planning \\
\hline NGO & Non-Governmental Organization \\
\hline NRT & Northern Rangelands Trust \\
\hline PES & Payment for Ecosystem Services \\
\hline PMCC & Pate Marine Community Conservancy \\
\hline SDF & State Department of Fisheries \\
\hline TNC & The Nature Conservancy \\
\hline UVC & Underwater Visual Census \\
\hline VMS & Vessel Monitoring System \\
\hline WIO & Western Indian Ocean \\
\hline WWF & World Wildlife Fund \\
\hline
\end{tabular}




\section{Abstract}

The oceanography, geology, connectivity with Gulf of Aden, diverse ecosystems and cultural world heritage are the Outstanding Universal Values of Lamu-Kiunga seascape. The oceanography supports a productive marine ecosystem that hosts a variety of marine species. The coral cover in 2015 averaged $16 \%$, with a range of $35 \%$ inshore $<5 \%$ on the deep offshore reefs. Globally, rare coral genera of Siderastrea, Horastrea, Caulastrea, Moseleya and endemic angelfish Apolemichthys xanthotis as well as six shark and nine ray species, Dugongs, turtles, whales and dolphin occur in the seascape. Mangrove cover and quality is good but has reduced over decades. The main threats to marine biodiversity include; increase in human population, high poverty levels, deforestation of mangroves, clay mining for pottery and land tenure. In response to these threats, public and civil institutions have engaged in providing solutions. Enactment of a wide range of national, coastal and environmental legislation is part of the policy response to the threats. The adoption of locally-managed marine areas has also improved management of marine biodiversity. It is envisioned that integrating local knowledge, government regulations and science through a marine spatial planning approach has the potential to benefit ecosystems and communities living around this unique part of Kenya's coast.

Keywords: marine ecosystems; marine species; coral cover; conservation 
The Biodiversity Management Programme (BMP) is an Intergovernmental Authority on Development (IGAD) initiative which aims to contribute to poverty reduction by improving the social and economic wellbeing of populations in the region, through better regional integration in the environmental sector. Its purpose is the conservation and sustainable management of ecosystems in order to contribute to lasting ecosystem goods and services. ICRAF is one of BMP's Implementing Partners (IPs) and is managing one of the three projects aimed at developing collaborative management in three cross-boundary land and seascapes between Kenya-Somalia, Djibouti-Ethiopia and Ethiopia-South Sudan. The initiative is funded by the European Union (EU).

The ICRAF-led project (November 2013-November 2017) is being implemented in the cross-border area of northeastern Kenya and southern Somalia in an area extending from the Tana River in Kenya to the Laga Badana Bush Bush National Reserve in Somalia. This paper addresses one of the project aims of sourcing biodiversity information and providing a synthesis of threats and opportunities. As a partner on the ICRAF project, CORDIO East Africa was tasked with contributing to this activity by leading the compilation and synthesis of information on marine biodiversity in the northern Kenya part of the seascape from Lamu to the Somali border at Kiunga. With additional funding from The Nature Conservancy (TNC), CORDIO East Africa was able to survey the Pate to Kiunga coastal marine habitats in 2015.

The purpose of the study was to assess the near-shore coastal marine environment, its current and potential use and benefits of ecosystem services to people, and the drivers and pressures of change in the seascape, as well as opportunities for improved management.

This study sought to determine the current status of the marine biodiversity in the area, with a particular focus on coral reefs and mangroves as the two dominant marine habitats in this seascape. Current management of the national marine reserves, and information on other key aspects of this seascape such as coral health, ecologically valuable habitats, vulnerable and threatened species, ecosystem services and resilience to climate change were also assessed. 
The Lamu-Kiunga seascape is located in the northern part of Kenya's coast between $1.6537^{\circ} \mathrm{S}$, $41.5598^{\circ} \mathrm{E}$ and $2.4776^{\circ} \mathrm{S}, 40.7060^{\circ} \mathrm{E}$. The area borders Somalia. It has many valuable marine resources, such as mangroves, coral reefs and seagrasses, which provide an important source of livelihood and food security for local communities. Management of Pate Island and Kiunga area has embraced the use of community conservancies, anchored in the Wildlife Conservation and Management Act 2013, and established through a partnership between communities, government, The Nature Conservancy and Northern Rangelands Trust (NRT). Pate Marine Community Conservancy (PMCC) and Kiunga Marine Community Conservancy (KMCC) were established in 2013: PMCC is in charge of coordination of conservation measures in four management units (blocks) of Pethali, Rewa, Uvondo and Siyu while KMCC is responsible for Mkokoni, Kiwayu, Rubu, Kiunga and Ishakani (Figure 1). It is anticipated that the integration of local traditional knowledge on environment with modern science and research will improve the management of finite resources.

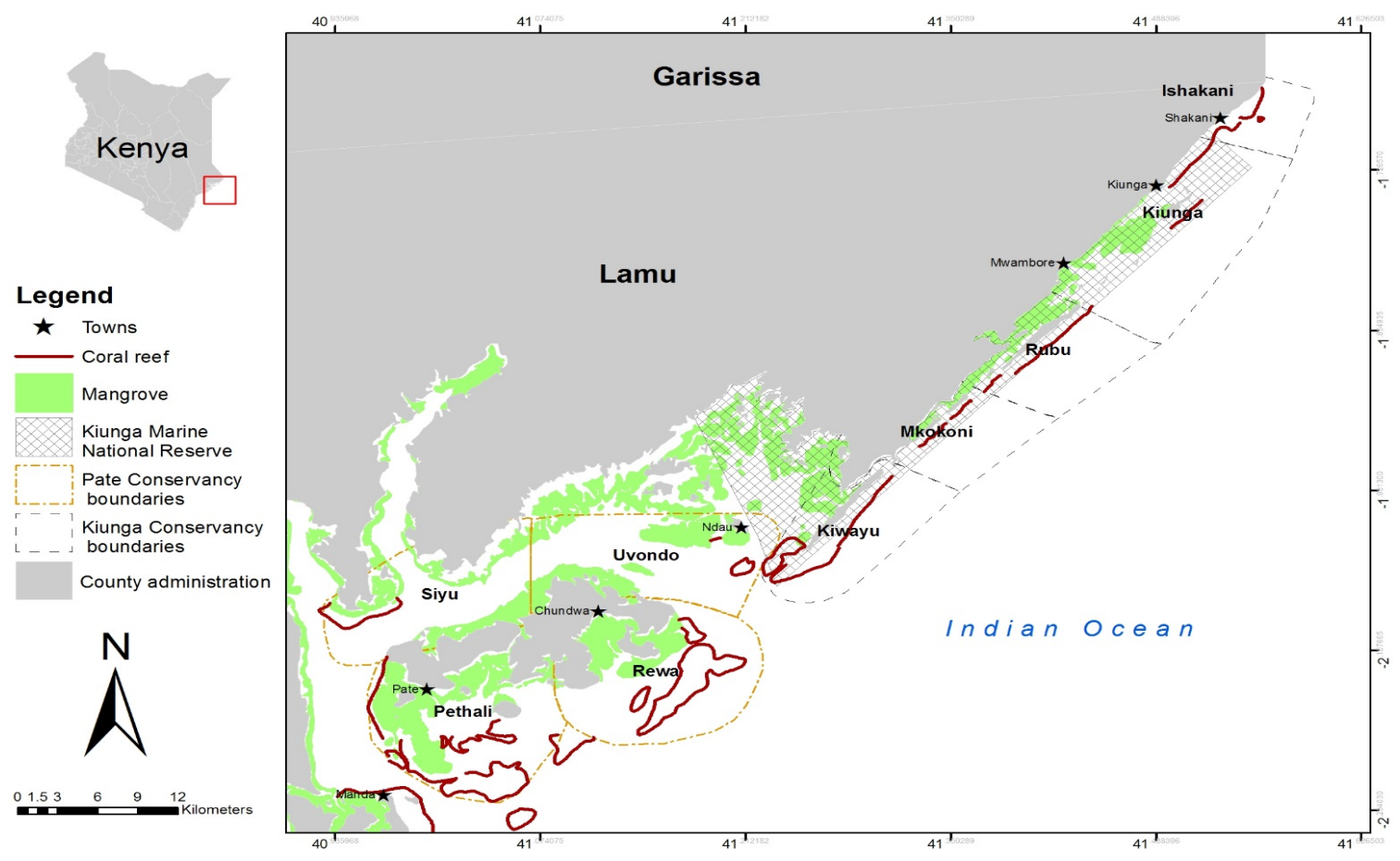

Source: NRT-Coast

Figure 1: Map of coastline showing Kiunga Marine National Reserve and the conservancies

\section{Physiography of the seascape}

The seascape has a continental shelf spreading about $4-6 \mathrm{~km}$ off the mainland. The coral reef type is characterized by patchy and fringing reefs with offshore deep reef terraces. The deep reef extends about $4 \mathrm{~km}$ offshore to the edge of the continental shelf, while the raised fossil reef onshore are mostly covered with sand dunes such as the Kiwayu Island, which support halophytic shrubs, grasses and woodland. The geology of the islands comprises the fossilized sand dunes and beaches of the Pleistocene age (Weru et al. 2001). The coastline of Lamu seascape and northeastwards along Somalia is mostly rocky with few indentations and is rimmed by a narrow beach. The rocks consist of 
Quaternary sediments that are in contact with Jurassic sediments and the Precambrian basement (Pepper and Everhart 1963).

\section{Geology and oceanography}

The ocean floor of Lamu-Kiunga seascape lies on the Indian Ocean Basin within the African plate, which broke up from Gondwanaland, the super continent, about 180 million years ago (Cande and Stegman 2011, Obura et al. 2012). The ocean floor has remained relatively unchanged making it a refuge for different marine species.

The broader Lamu-Kiunga archipelago represents the Northern Monsoon Coastal Current eco-region of Kenya (McClanahan 1988, Obura 2012). The Lamu-Kiunga area experiences monsoonal winds, East Africa Coastal Current (EACC) and Somali current that significantly influences the rainfall and sea surface temperatures (Schott et al. 2009). The influence of the Somali current with its cold upwelling waters is higher in the seascape compared to Kenya's southern coast, partly because of its proximity and due to the narrow width of continent shelf in the north compared with the south (Figure 2). The upwelling waters of the seascape enhance nutrient circulations for the primary and secondary productivity of the marine ecosystems, supporting marine life such as fish, crustaceans, molluscs and migratory species such as seabirds and turtles (Samoilys et al. 2015).

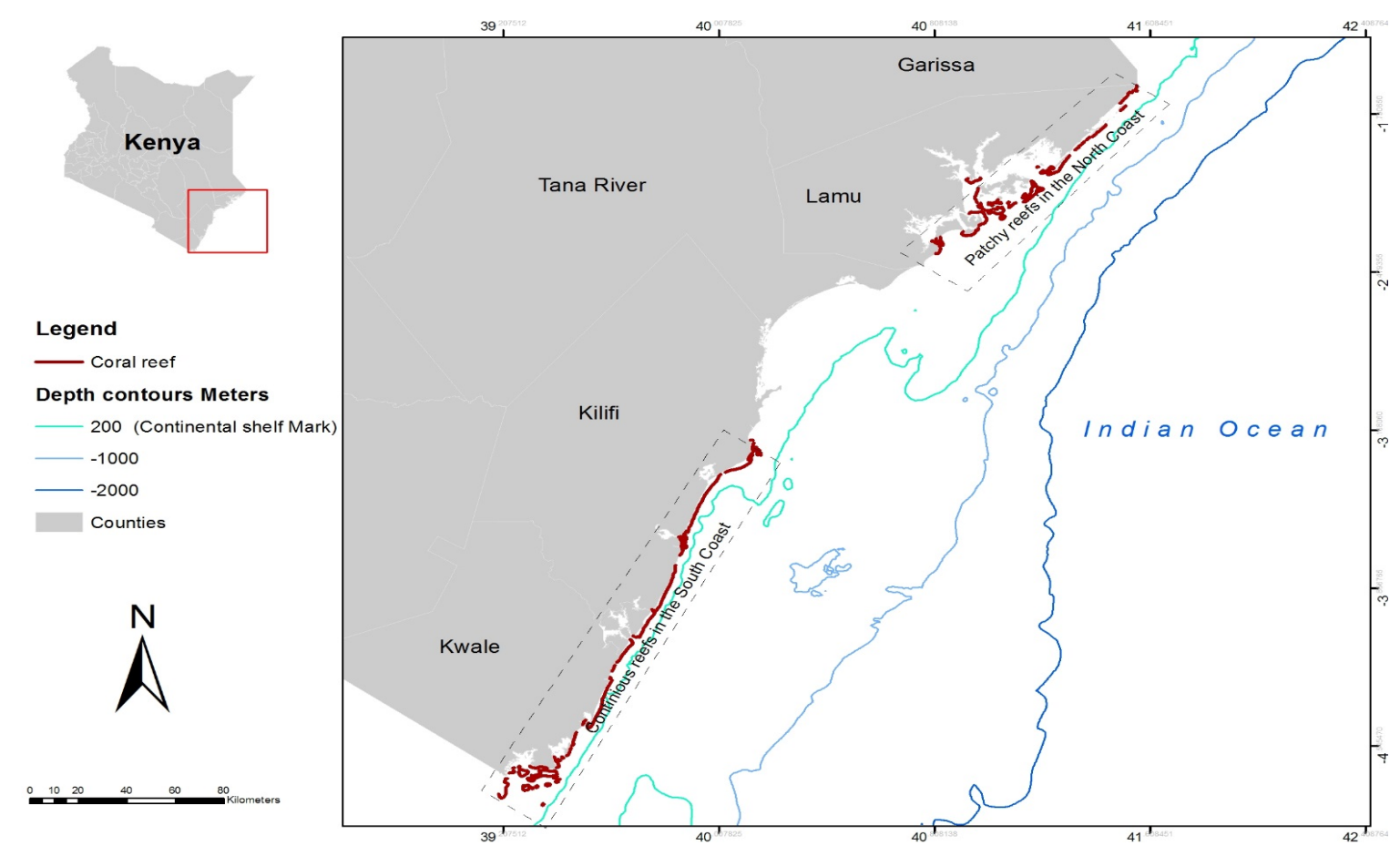

Source: Cordio East Africa

Figure 2: Spatial extent of coral reefs of the Kenyan coast and the 200m-depth contour

\section{Outstanding features of Lamu-Kiunga seascape}

The coral reef system in the area has a unique mix of coral and fish species representative of the East African and the Red Sea/Arabian Gulf fauna. Convergence of the East Africa Coastal Current (EACC) 
and the cold upwelling of the Somali current cause this. For instance, an endemic angelfish of the Red Sea/Gulf of Aden, Apolemichthys xanthotis is found in the area. The coral rag islands of Kiunga-Lamu archipelago also act as key nesting grounds for 10,000 breeding pairs of roseate terns (Sterna dougallii). Other birds include white-cheeked tern (Sterna represa), bridled tern (Sterna anaethetus), white pelicans (Pelecanus onocrotalus), and African spoonbill (Platalea alba) (Weru et al. 2001). There are also anecdotal reports of sightings of the Critically Endangered knifetooth sawfish (Anoxypristis cuspidate) and longcomb sawfish (Pristis zijron) south of Lamu in the lower reaches of the Tana River (Samoilys et al. 2011a).

The geology, oceanography, connectivity with Gulf of Aden, wide range of ecosystems from terrestrial and marine habitats, and cultural world heritage are some of the Outstanding Universal Values of the broader Lamu-Kiunga seascape. The seascape is endowed with unique habitats, extensive mangrove forests and resident and migratory species, making it an important global biodiversity site (Weru et al. 2001, Obura et al. 2012). 


\section{Biodiversity of shallow marine habitats}

\section{Introduction}

The habitats of Lamu-Kiunga seascape offer a wide range of ecosystem services from the complex carbon sequestration services, primary and secondary productivity to providing habitat and nursery grounds for numerous fish and shellfish (De La Cruz 1979, Carlton 1974). Shallow marine habitats found in Lamu-Kiunga seascape include coral reefs, seagrass and mangroves ecosystems that provide four ecosystem services of provisioning, regulating, cultural and supporting services.

Seagrass meadows provide numerous high value ecosystem services. They are vital habitat for marine organisms and form important foraging grounds for the endangered marine turtles and dugongs. Seagrass ecosystems are vital to the fishing industries as they serve as an important habitat and source of food to large fish species, for at least a part of their life cycle. They stabilize bottom sediments with their dense roots and rhizomes especially during storms. Seagrass beds also represent enormous carbon sinks and are being considered in blue carbon schemes (Samoilys et al. 2015).

\section{Coral reefs}

Coral reefs are among the most productive and diverse of all marine ecosystems. They control the ecology of near shore marine environments by providing habitat and shelter to a high diversity of fish families, lobsters, octopus, dugongs, turtles and whale sharks. They act as a buffer for ocean waves reaching the shore. Coral reef ecosystem supports both artisanal and commercial fisheries and hence forms the backbone of coastal communities' economies. Recreational activities in coral reef ecosystems support the tourism industry, which subsequently engages other stakeholders such as boat operators, tour companies, tour guides and hoteliers in the hospitality sector.

Coral reefs in Kenya extend from the Tanzanian border in the south to the Somali border in the north and cover an area of $621.55 \mathrm{~km}^{2}$ representing $0.2 \%$ of the Great Barrier Reef (Figure 2). Kenya's coral communities conform to those of the western and central Indian Ocean biogeographic zone, with some endemic species and others of wide Indo-Pacific distribution (Obura 2012). The reefs are typically composed of hard substrate co-existing closely with extensive sea grass communities as described by Rosen (1971). A continuous fringing reef dominates the southern part of Kenyan reefs while patchy and in places marginalized reefs characterize the northern part including the Pate Island to Kiunga area. These contrasting formation patterns between the southern and the northern reefs is attributed to the unique biophysical characteristics of the northern coast notably the fresh water discharge from the Tana and Sabaki Rivers coupled with the nutrient rich Somali current running south from Somalia (Survey of Kenya 2009, Obura et al. 1998).

\section{Coral diversity}

The coral reef survey in 1998 in the Pate Island-Kiunga Reserve area identified 51 genera and 146 species of corals with the reefs of Simbabaya, Kui and Bomani being more diverse than other reefs (Obura et al. 1998). Surveys done in 2000s show presence of 180 species of corals in the Lamu-Kiunga 
seascape (Obura et al. 2012). The unique corals species in the seascape include Porites nodifera, $P$. columnaris, and Coscinaraea species (Hamilton and Brakel 1984, Obura 2008). Globally rare coral genera of Siderastrea, Horastrea, Caulastrea, and Moseleya have also been encountered in previous coral surveys (Obura et al. 1998). The rare and endemic corals comprise Horastrea indica and Siderastrea savignyana. Goniopora sp. is also present especially off Pate Island (Samoilys et al. 2011a).

Forty-four coral genera were recorded across all the sites (Appendix 1). The site-level species richness varies from highs of 26 genera on many of the deep reefs at Chole, 25 genera at Shimo la Tewa, to lows of 16-17 genera at Kui, Kupi and Pethali, all inner patch reefs. By contrast, species richness was greatest on the shallow reefs (Shimo la Tewa, Chole, Iweni) and lowest on two deep reefs (Mongo Shariff, Ch. Rubu) and two inner reefs (Pethali, Kui). Reef sites were strongly dominated by Porites followed by about 15 genera that decreased progressively in relative abundance, and included Favites, Goniastera, Coscinaraea, Favia. Eight genera were scarce, only found once in the entire survey. This includes the endemic genus Craterastrea, which until now had been reported only within the high diversity centre in the northern Mozambique Channel, as well as from Chagos (British Indian Ocean Territory). Genus richness is generally low, compared to $>50$ genera recorded and $>300$ species expected at sites in the northern Mozambique Channel (Obura 2012).

\section{Coral reef benthos}

Coral reefs globally are facing a decline in cover and change in species composition due to stressors such as climate change, pollution, overfishing and harmful algal blooms. Estimates indicate that globally approximately $34 \%$ of the coral reefs have been destroyed or are declining (Pandolfi et al. 2011). Global trends show a decline in hard coral cover, which has accelerated in the last few decades (Pandolfi et al. 2003, Carpenter et al. 2008). Coral reefs of the northern offshore Kiunga area are predominantly algal reefs with some patch coral habitats, particularly nearshore, with coral cover of around $4 \%$ on the offshore deep reef slopes of Kiunga Marine Reserve (Samoilys 1988). Hard coral cover estimates in 1987 on the deeper offshore reefs of Rubu, Mkokoni and Kiwayu was $<5 \%$. In 2006, the latest year surveyed during the nine-year WWF/CORDIO programme, the cover of hard corals ranged widely, from 5-24\%, depending on the site within the Pate-Kiunga area (Figure 3a). The cover of soft corals in the 1980s ranged from 2.9-5.6\% compared to $0.1-8 \%$ in 2006 (Figure 3b). Hard coral, soft coral and coralline algae cover all declined significantly in all areas of Kiunga Marine National Reserve and around Pate Island following the 1998/1999 coral bleaching, and then gradually recovered over subsequent years (Figures 3a-c).

In contrast, the brown macro-algae Sargassum sp., Turbinaria sp. and Hormophysa cuneiformis, increased after the 1998 bleaching event to the highest level recorded of $>86 \%$ and then later dropped, but to levels that were always higher than the pre-bleaching level (Figure 3d). In 2006 macroalgae cover was between $42 \%$ and $79 \%$ in the Pate-Kiunga area. This increase in macro-algae corresponds to a reduction in hard coral cover. Studies on coral conditions and recruitment within Kiunga Marine National Reserve, conducted systematically from 1998 to 2002 further underscore a low recruitment in 1999, likely due to mortality following the 1998 coral bleaching and reduced reproductive output of surviving corals (Table 1). While the cover of corals in the Pate Island-Kiunga seascape is generally well below the average cover of Kenyan reefs (20-30\%), by 2000 the cover had 
stabilized, but on average at lower levels than pre-bleaching levels. However, some sites had recovered to higher levels within the nearshore Kiwayu and Pethali areas and are within the range of national coral cover (Figure 3a).
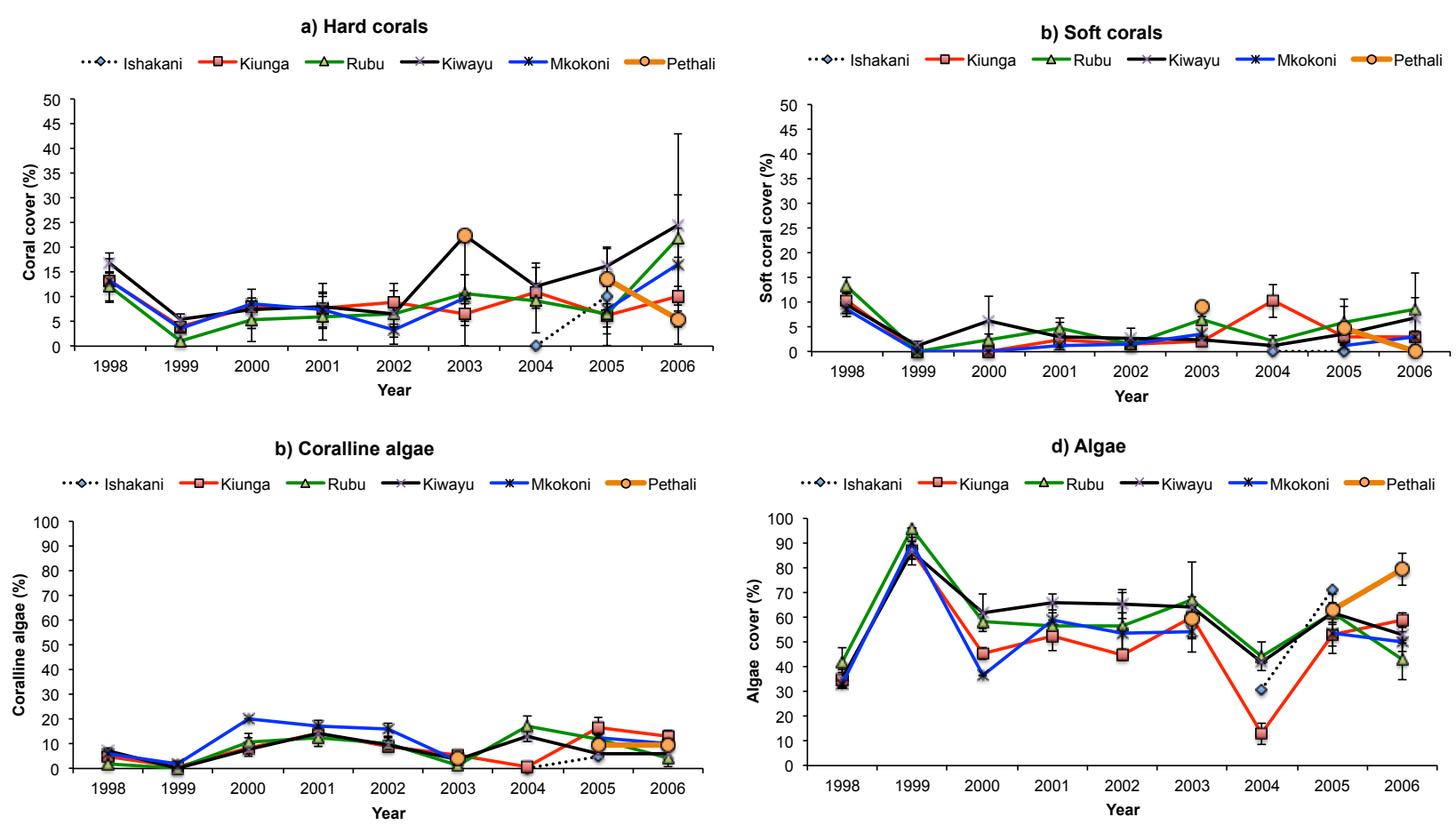

Figure 3: Change in the cover of benthic variables: a) hard coral, b) soft coral, c) coralline algae and d) brown macro-algae, from 1998 to 2006 in the Lamu-Kiunga area (Data source: CORDIO/WWF) See appendix 2 for data treatment and analysis

From the coral reef surveys conducted in 2015 to determine the current status of reefs in the area (Figure 4 ), the coral cover of Pate-Kiunga area averaged $16 \%$ across the sites, from a maximum of 35\% at Iweni to minimum of $<5 \%$ on the deep reefs at Rubu, Mongo Shariff, Chano and Mvundeni. These measures are not markedly different from 2006, though the measure of 35\% at Iweni is higher than any previous years. Coralline algal cover was low at most sites, but with higher levels at $\mathrm{Ch}$. Chano (>20\%) and Ch. Mvundeni (10\%). However, these are not higher than levels nine years ago. In 2015, turf algae were the dominant cover across all sites at an average of $38 \%$, followed by hard corals (16\%) then macro algae (13\%). Macro-algal cover is now substantially lower than it was in 2006. Macro algal cover did vary between sites with higher cover at three deep reefs (Rubu, Mongo Shariff and Mvundeni) and two shallow reefs (Kui and Pethali). Reasons for these site differences are not clear, possibly due to site differences in nutrient enhancement from neighboring mangroves or upwelling. 


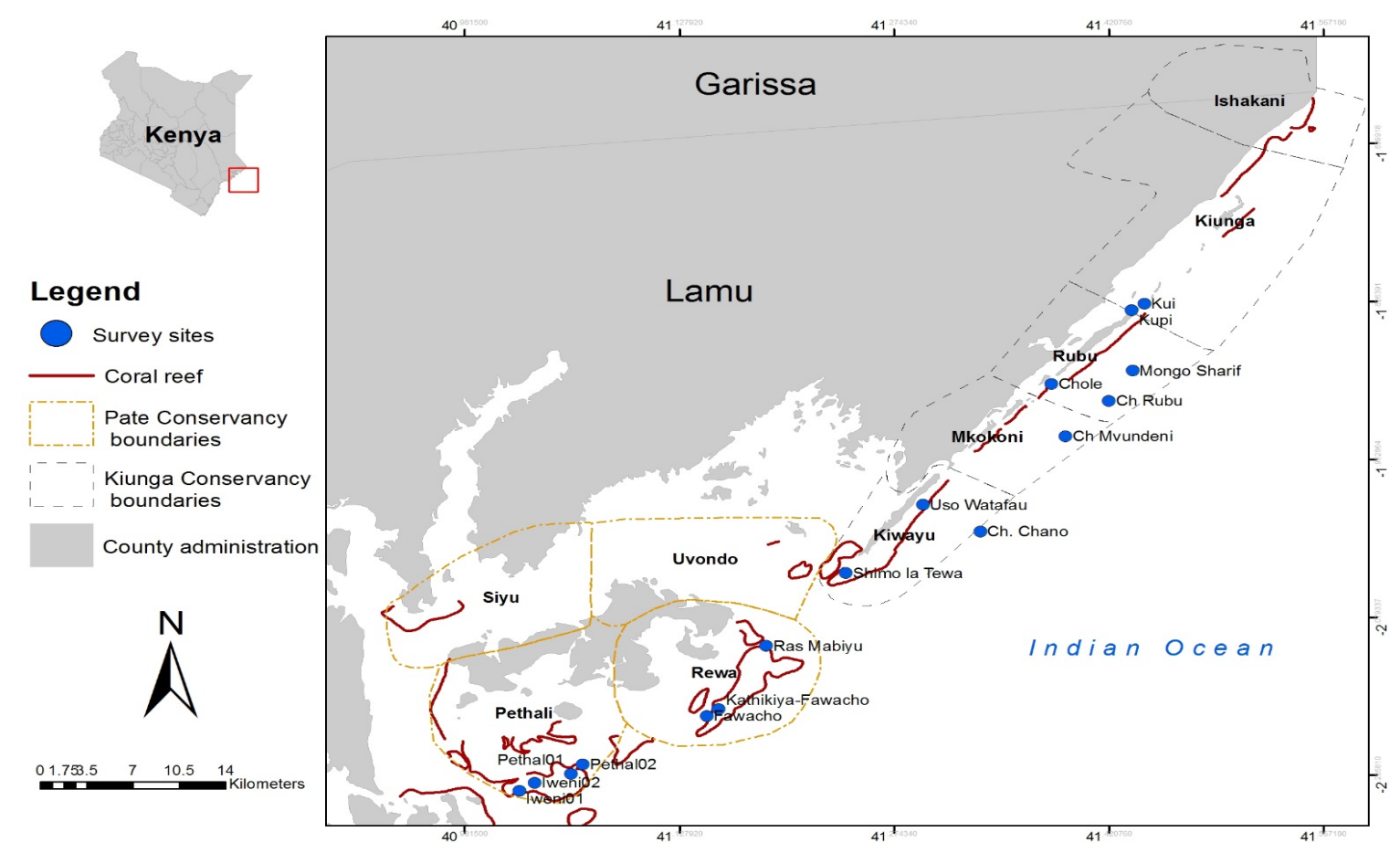

Source: Cordio East Africa

Figure 4: Map of in-situ coral reef survey sites conducted by CORDIO through support from TNC in 2015 in the conservancies established under the NRT Coast programme.

Table 1: Densities of coral adults and recruits sampled in Kiunga Marine National Reserve from 1998 to 2002

\begin{tabular}{lcrrrr}
\hline & 1998 & 1999 & 2000 & 2001 & 2002 \\
\hline Number of slites & 6 & 12 & 16 & 16 & 14 \\
Total area sampled, $\mathrm{m}^{2}$ & 120 & 317 & 179 & 192 & 234 \\
Area sampled per site (ave) & 20.0 & 26.4 & 11.2 & 12.0 & 16.7 \\
& & & & & \\
Number of colonles sampled: & & & & & \\
Overall & 709 & 1115 & 1053 & 1628 & 1998 \\
Adults & 709 & 1097 & 703 & 1270 & 1822 \\
Recrults & $\mathrm{n} / \mathrm{a}$ & 18 & 350 & 358 & 176 \\
& & & & & \\
Density (per $\mathrm{m}^{2}$ ) & & & & & \\
Overall & 5.9 & 3.5 & 5.9 & 8.5 & 8.5 \\
Adults & 5.9 & 3.5 & 3.9 & 6.6 & 7.8 \\
Recruits & $\mathrm{n} / \mathrm{a}$ & 0.1 & 2.0 & 1.9 & 0.8 \\
\hline
\end{tabular}

Source: Obura and Church 2003

\section{Coral mortality and bleaching}

Increases in sea surface temperature coupled with various use of coral reefs by coastal communities have increased pressures on coral reefs. The 1998/1999 El Nino led to bleaching of more than $80 \%$ of the coral reefs in the Lamu-Kiunga seascape (Obura et al. 2007). Stressors such as harmful algal blooms and disease as witnessed in January-March 2002, as well as bleaching remain the primary cause of coral mortality in the area (Church and Obura 2004). Other than that, the economic development witnessed in Kenya over the past few years has seen major projects commence in the northern coast, 
notably the Lamu Port Southern Sudan-Ethiopia Transport (LAPSSET) project and oil explorations. These activities are likely to further affect the corals in the area, but the impact of these activities remains to be assessed.

\section{Resilience status of reefs}

Globally coral reefs have demonstrated some form of resilience and resistance to both physical and biological stressors such as fluctuations in seawater temperature. For example, in the Persian Gulf, reefs have demonstrated resilience by thriving under extreme conditions of fluctuating water seawater temperatures. Such scenarios have also been documented in Kenya where the reefs showed good recovery after the 1997/1998 bleaching and after instances of coral diseases caused by harmful algal blooms in 2002 (Church and Obura 2004). Following the El Niño Southern Oscillation (ENSO) event, the coral reefs of the KMNR showed varying levels of resistance and resilience to bleaching (West and Salm 2003, Obura 2004, 2012). Bleaching was evident everywhere but mortality was least in the inner channel reefs demonstrating resilience and resistance to bleaching as a result of influence on turbidity and water flow (Obura and Church 2004). However, resilience in the overall system declined dramatically in 2002 because of coral disease culminating in decreased coral cover and recruitment. With indications of a rising seawater temperature within the next 50 years on the East African coast, management measures are urgently required to increase resilience of coral reefs along the Lamu-Kiunga seascape.

\section{Coral reef fish diversity}

Over 30 genera and 150 species of fish were reported in the Kiunga Reserve in 2001 (Weru et al. 2001). Deeper fore reefs as well as inner reefs of Kui, Boma and Rubu reefs showed high diversity of fish species. Notable fish species found in the Lamu-Kiunga seascape include Red Sea/Arabian Gulf angelfish Apolemichthys xanthotis and the Endangered Napoleon wrasse Cheilinus undulatus. A total of 189 species of reef fish were observed during the Pate to Kiunga 2015 survey (Appendix 3), out of a total number for the WIO of >350 in the 19 families surveyed (Samoilys and Alvarez Filip 2012). This diversity is low, compared with reefs further south in Tanzania and Mozambique, but to be expected for these northernmost east African reefs, which are marginal. Species richness based on the list of 19 families ranged from 45 at Chongo Chachano/Mvundeni (combined sites) to 81 at Kui (Table 2). Families that were notably poorly represented were the Pomacentridae and Labridae, two of five most speciose families that are considered the best indices for assessing reef fish diversity and are used in the Coral Fish Diversity Index (CFDI) by Allen and Werner (2002). Numbers of species of these families and the chaetodontids were very low at Chongo Chachano, Mvundeni, Rubu and Mongo Shariff (Table 2). These are the offshore deep plateau type reefs dominated by algae. Clearly species richness improves on the inner reefs and bays where there is more coral formation, as seen in the CFDI families and the total species counts at these other inner sites. Comparisons with other reef systems further south on the east African coastline and in Madagascar help put these values in perspective, with total species counts in NE Madagascar at 271 and northern Mozambique at 263 (Table 2). Species diversity for balistids and haemulids is relatively high at the Lamu-Kiunga sites while the species diversity for scarids and serranids is very low. 
The CFDI diversity index provides a relative global index for assessing reef fish diversity as a measure of reef health. The overall CFDI for the Pate- Kiunga reefs was 122, considerably lower than that of reefs elsewhere in the WIO (Table 3). Fawacho and Ras Mabiyu in Pate Conservancy both scored the highest CFDI at 55, with Kui at 51 and Iweni and Pethali both with 42. Other inner sites in Kiunga scored $<36$ (Table 2). 
Table 2: Total number of reef fish species per family per site

\begin{tabular}{|c|c|c|c|c|c|c|c|c|c|c|c|c|c|}
\hline \multirow[b]{2}{*}{ Family } & \multirow[b]{2}{*}{$\begin{array}{l}\text { Madag- } \\
\text { ascar } \\
2010\end{array}$} & \multirow[b]{2}{*}{$\begin{array}{l}\text { North } \\
\text { Mozamb } \\
2015\end{array}$} & \multirow[b]{2}{*}{$\begin{array}{l}\text { All } \\
\text { sites } \\
\text { Lamu- } \\
\text { Kiunga }\end{array}$} & \multicolumn{2}{|c|}{ Pethali } & \multirow{2}{*}{$\begin{array}{l}\text { Fawacho } \\
\text { Fawacho }\end{array}$} & \multirow{2}{*}{$\begin{array}{l}\text { Ras } \\
\text { Mabiyu } \\
\text { Ras } \\
\text { Mabiyu }\end{array}$} & \multicolumn{2}{|l|}{ Kiwaiyu } & \multirow{2}{*}{$\begin{array}{l}\text { Kiw/Rubu } \\
\text { Chano/Mvun } \\
\text { d }\end{array}$} & \multicolumn{2}{|l|}{ Rubu } & \multirow{2}{*}{$\begin{array}{l}\text { Kiunga } \\
\text { Kui }\end{array}$} \\
\hline & & & & Iweni* & Pethali & & & $\begin{array}{l}\text { Shimo } \\
\text { la } \\
\text { Tewa* }\end{array}$ & $\begin{array}{l}\text { Uso } \\
\text { Watafau* }\end{array}$ & & Chole* & $\begin{array}{l}\text { Rubu/ } \\
\text { Sharif }\end{array}$ & \\
\hline Pomacentridae* & 38 & 40 & 30 & 13 & 10 & 20 & 13 & 5 & 11 & 4 & 6 & 6 & 13 \\
\hline Pomacanthidae* & 6 & 7 & 4 & 1 & 1 & 3 & 3 & 1 & 1 & 2 & 0 & 2 & 2 \\
\hline Chaetodontidae* & 22 & 21 & 17 & 6 & 4 & 7 & 2 & 2 & 1 & 4 & 2 & 5 & 6 \\
\hline Scaridae* & 20 & 26 & 9 & 3 & 3 & 6 & 4 & 6 & 2 & 1 & 3 & 2 & 6 \\
\hline Acanthuridae* & 28 & 23 & 22 & 4 & 7 & 6 & 9 & 10 & 5 & 6 & 7 & 11 & 10 \\
\hline Serranidae & 14 & 18 & 8 & 0 & 1 & 1 & 4 & 2 & 1 & 1 & 1 & 2 & 4 \\
\hline Lethrinidae & 10 & 9 & 3 & 2 & 1 & 1 & 1 & 1 & 2 & 0 & 0 & 1 & 1 \\
\hline Lutjanidae & 11 & 10 & 7 & 4 & 1 & 2 & 2 & 2 & 5 & 1 & 3 & 1 & 6 \\
\hline Caesionidae & 7 & 8 & 7 & 2 & 2 & 3 & 5 & 2 & 1 & 1 & 3 & 1 & 3 \\
\hline Nemipteridae & 2 & 3 & 1 & 0 & 0 & 0 & 0 & 0 & 1 & 0 & 1 & 0 & 0 \\
\hline Mullidae & 8 & 6 & 6 & 1 & 4 & 1 & 0 & 1 & 2 & 1 & 2 & 3 & 4 \\
\hline Siganidae & 6 & 6 & 4 & 2 & 2 & 1 & 1 & 1 & 1 & 0 & 2 & 1 & 1 \\
\hline Balistidae & 12 & 9 & 10 & 1 & 0 & 0 & 0 & 0 & 0 & 6 & 0 & 10 & 1 \\
\hline Monacanthidae & 7 & 2 & 1 & 0 & 1 & 0 & 0 & 0 & 0 & 0 & 0 & 0 & 0 \\
\hline Ostraciidae & 2 & 5 & 2 & 0 & 1 & 0 & 0 & 0 & 1 & 1 & 0 & 1 & 0 \\
\hline Tetraodontidae & 8 & 8 & 4 & 2 & 1 & 1 & 1 & 0 & 3 & 0 & 1 & 1 & 1 \\
\hline Carangidae & 7 & 4 & 5 & 0 & 0 & 0 & 0 & 0 & 0 & 1 & 1 & 2 & 1 \\
\hline Total & 271 & 263 & 189 & 57 & 58 & 68 & 72 & 48 & 53 & 45 & 48 & 75 & 81 \\
\hline
\end{tabular}

Values from Madagascar and Mozambique are provided for comparison. ${ }^{*}=5$ families used to calculate the Coral Fish Diversity Index (CFDI). Blue=Pate; pink=Kiunga sites 
Table 3: Coral reef fish diversity index (CFDI) values for Lamu-Kiunga and from other WIO countries

\begin{tabular}{|l|l|l|}
\hline Location & CFDI & Source/date of survey \\
\hline Lamu-Kiunga & 122 & CORDIO-TNC survey/2015 \\
\hline $\begin{array}{l}\text { Mozambique - Mocimboa and } \\
\text { Palma }\end{array}$ & 167 & Samoilys et al. 2015/2015 \\
\hline Northeastern Madagascar & 172 & $\begin{array}{l}\text { Samoilys and Randriamanantsoa } \\
2011 / 2010\end{array}$ \\
\hline Northwestern Madagascar & 176 & Allen 2005/2002 \\
\hline $\begin{array}{l}\text { Comoros - Grande Comore and } \\
\text { Moheli }\end{array}$ & 147 & Samoilys unpubl., 2010 \\
\hline
\end{tabular}

CFDI = total no. species in 6 families: Chaetodontidae, Pomacanthidae, Pomacentridae, Labridae, Scaridae and Acanthuridae. Source: Allen and Werner 2002

\section{Trends in fish abundance}

Comparisons of the fish surveys conducted using standard underwater visual census (UVC) methods (Samoilys and Carlos 2000) from 1999 to 2008 (surveys by WWF/CORDIO), reveal variability in fish densities of 11 selected families across the years and management areas (Figure 5). The densities of seven families in 1987 at three areas of Rubu, Mkokoni and Kiwayu were added as reference points. The densities of acanthurids, haemulids, lutjanids, lethrinids and scarids were significantly different with respect to years and areas $(p<0.05)$. Chaetodontids, serranids and siganids showed significant differences across years. The density of Acanthuridae remained low after the 1997/8 El Niño. However, in 2001 a sharp increase in their densities was witnessed in Rubu. This may be a result of the presence of schooling fish feeding on the high algal cover on the reefs.

The Balistidae have shown stable densities in all areas since 1998 (Figure 5). The high numbers experienced in 2001 could result from increased sea urchins, which had invaded the degraded reefs after the El Niño event. Balistids feed on sea urchins and may be important in controlling their populations. Carangidae, which are piscivores have remained relatively low. Chaetodontidae, which are good indicators of coral reef health were low in 1999, likely due to loss of coral cover following the El Niño event. Their continuous presence in Mkokoni, Rubu and Kiunga management areas, although in low densities, suggests a gradual recovery of corals. Popular food fish in local fisheries (Siganidae, Lethrinidae, Lutjanidae, Scaridae, Haemulidae) showed variability in density over the years. The presence of omnivores (Haemulidae, Lethrinidae) may indicate relatively diverse coral reef habitat due to their diet of small fish, invertebrates and dead animals. Decadal trends suggest that, lethrinids density declined in the 2000s when compared to the 1980s. On the other hand, scarids showed higher abundances in the 1990s compared to 1980 s and 2000 s.

From the 2015 survey, the densities and biomass of fish varied by site and family (Figure 6). By site, Mongo Shariff showed the highest densities of fish but strongly dominated by balistids $(164 \pm 44$ $1000 \mathrm{~m}^{2}$ ), specifically the planktonic Odonus niger. The lowest densities of fish were found at Chongo Mvundeni, which was dominated by acanthurids $\left(30 \pm 6\right.$ per $\left.1000 \mathrm{~m}^{2}\right)$ (Figure 6). Acanthurids, chaetodons, pomacanthids and scarids were present in all the surveyed sites while the other families 
were either missing or present in a few sites. The biomass was higher at Kui than other sites mainly due to large sized lutjanids $\left(103.8 \pm 100.9 \mathrm{~kg} / 1000 \mathrm{~m}^{2}\right)$, scarids and acanthurids. Also observed at this site was a juvenile giant grouper, Epinephelus lanceolatus, estimated at $86 \mathrm{~cm}$ in length. In contrast, Chongo Rubu, Shimo la Tewa and Chongo Mvundeni had the lowest biomass of fish families. In summary, across all sites and families, densities were generally lower in 2015 than in 2006 (Figures 5 and 6).

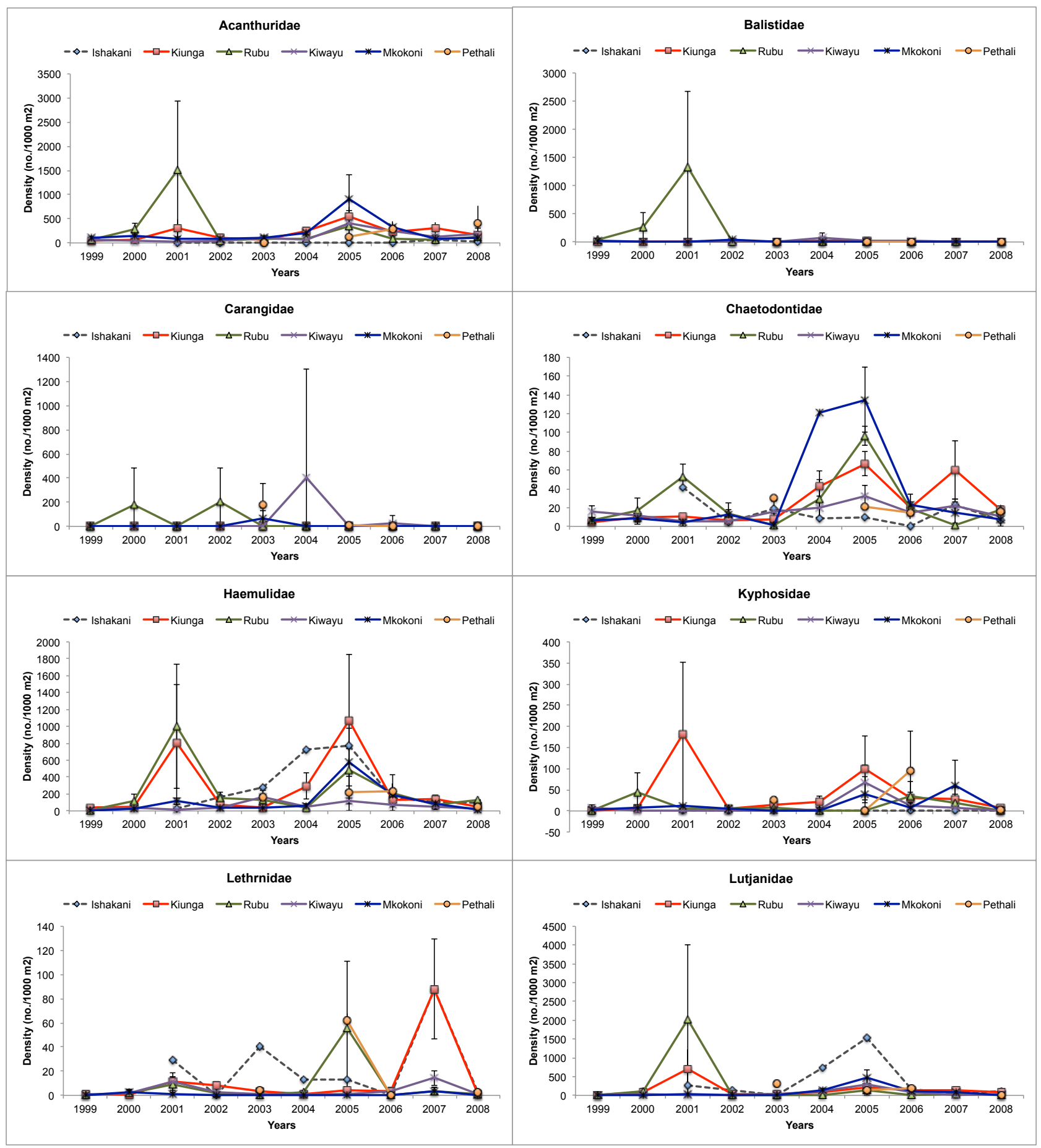




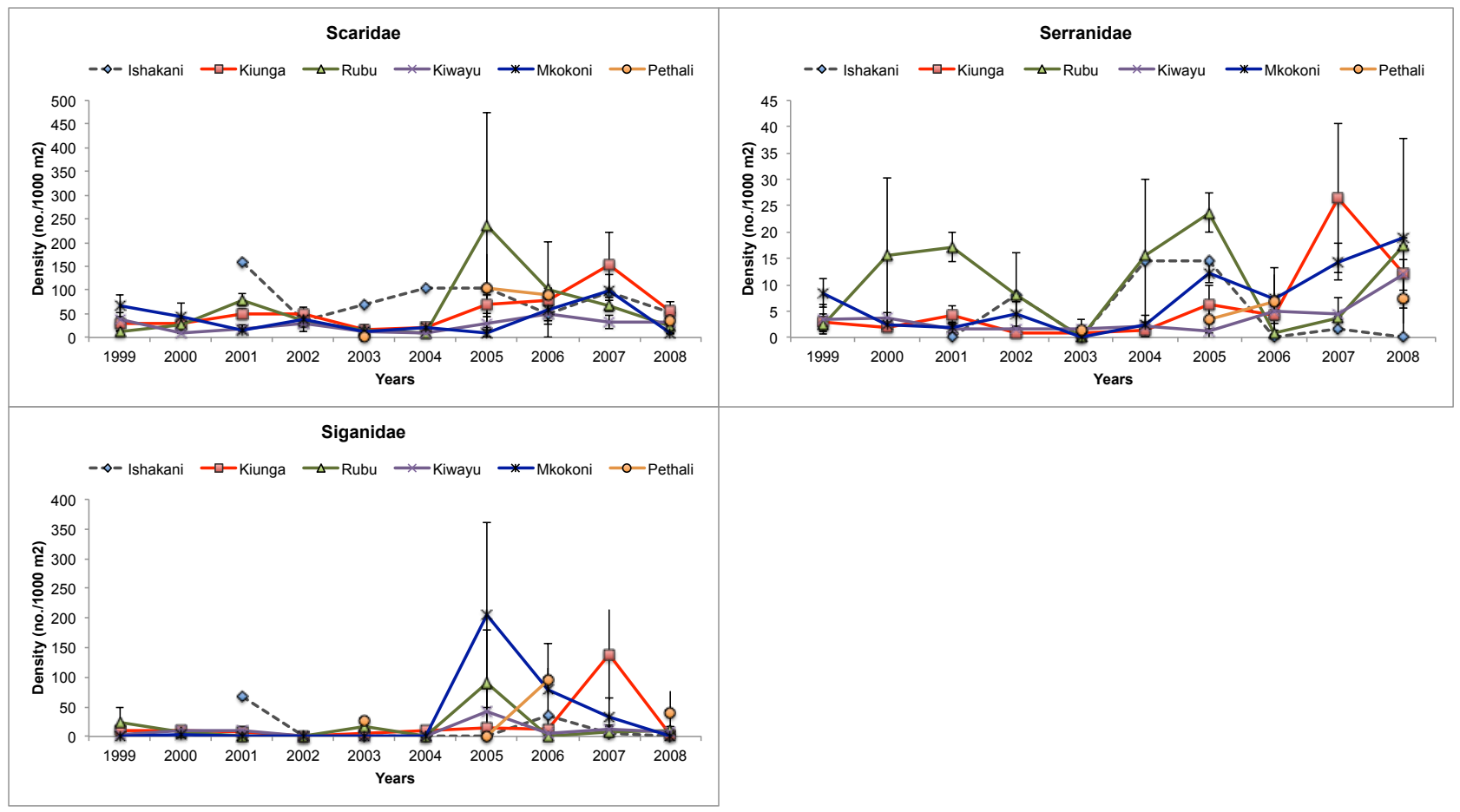

Data source: WWF/CORDIO

Figure 5: Fish abundance of 11 selected families in Kiunga-Pate seascape 


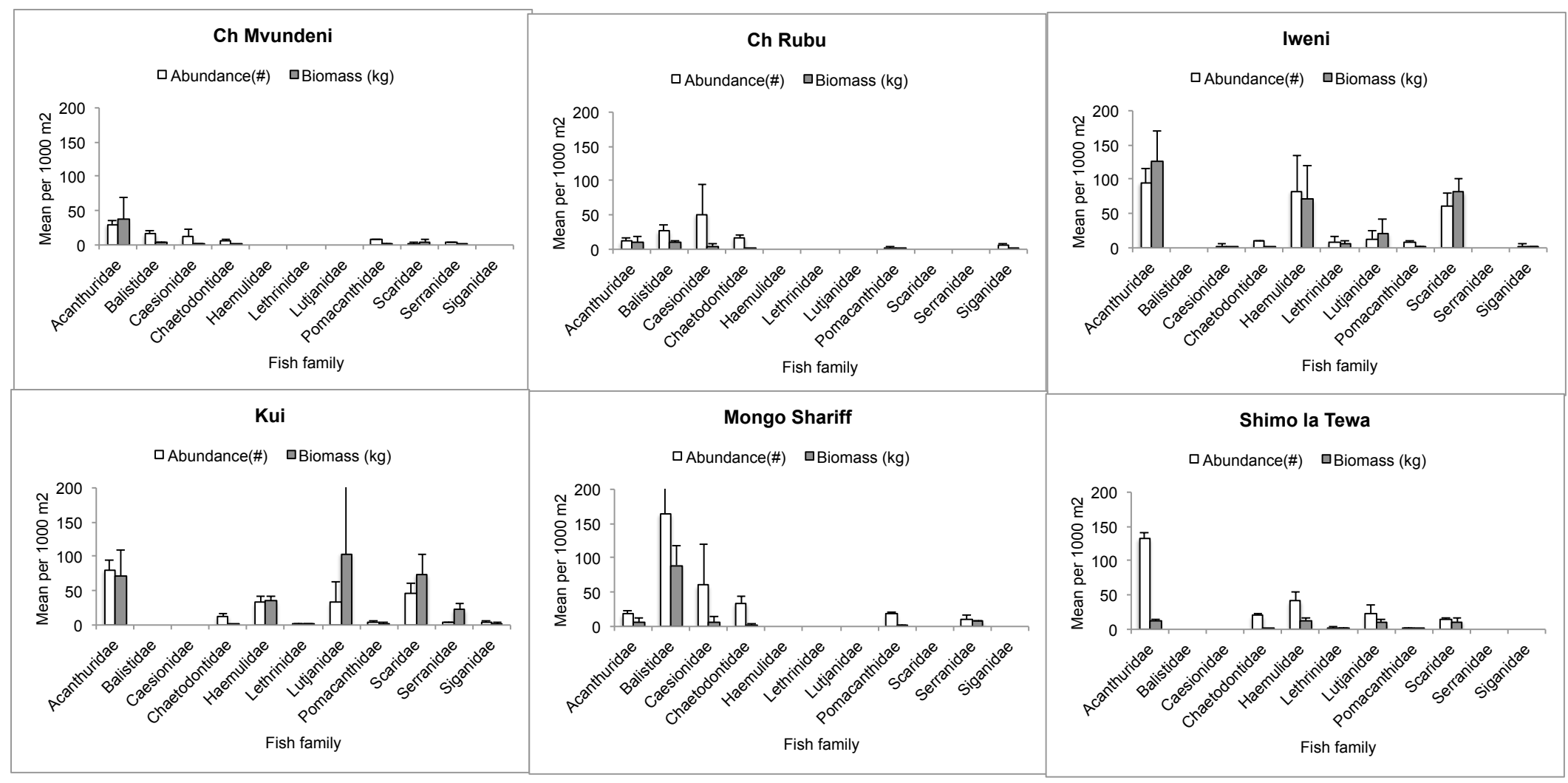

Figure 6: Mean density and biomass of fish families surveyed at six sites in Pate Island-Kiunga area in 2015 


\section{Seagrass}

Seagrass are submerged flowering plants found in shallow marine waters, such as bays and lagoons along continental shelves. They are distributed from intertidal to subtidal soft and hard bottoms, comprising coral reef patches, mud flats, lagoons, sandy bays, estuaries, and sheltered and exposed reef platforms. They show clear zonation patterns with water depth, sediment structure and exposure to air and sunlight during low tide. They are an important carbon and nutrient sink; act as a habitat for migrating coral reef species, waterbirds, fish, dugongs and turtles; and are critical to fisheries and coastline protection (Nagelkerken 2009). Seagrass meadows also play a role in attenuating the currents and waves. In doing so they trap suspended organic matter in the sediment. Provisioning services of seagrass beds include supporting commercial, subsistence and recreational fisheries.

The seagrass beds within the Lamu-Kiunga area are extensive, but little studied, and forms one of the most important habitats for marine fauna such as turtles and dugongs (Church and Obura 2006). The status of these species is treated later on in this report. The dominant seagrass in Lamu-Kiunga area is Thallasodendron ciliatum (Church and Obura 2006), though Syringodium isoetifolium, Cymodocea serrulata, C. rotundata, Halodule wrightii, H. uninervis, Enhalus acroroides and Zostera capansis are also present (WWF 1996, Samoilys et al. 2011a). Seagrass beds have not been quantified over years in the Lamu-Kiunga seascape, and only recently in 2015 have Kenya Wildlife Service initiated surveys of the seagrass beds of this area; data are not yet available.

\section{Mangroves}

Mangrove ecosystems are characteristically dominant features along the tropical and subtropical coastline and are among the most productive ecosystems with a mean production of $8.8 \mathrm{tC} / \mathrm{ha} / \mathrm{yr}$ (Jennerjah and Ittekkot 2002). Kenya's mangroves are found along the entire coast, which spans approximately $640 \mathrm{~km}$ from latitude $1^{\circ} 40^{\prime}$ North at Somali border to latitude $4^{\circ} 40^{\prime}$ South at the Tanzanian border (Figure 7). Two communities of mangroves formation, fringe and creek, occur along the coastline with the largest formation being in Lamu and Tana Delta (Ferguson 1993, Kairo et al. 2001).

\section{Mangrove cover}

The Lamu-Kiunga seascape hosts the largest stands of mangrove forests representing over $60 \%$ of Kenya's mangroves (Kairo 1995, GoK 2009). The standing mangrove biomass of the seascape (Mlango wa Chano to Kiunga) was about 480t/ha in the late 1990s (Weru et al. 2001) and a stand density of over $80 \%$ and height greater than $10 \mathrm{~m}$ was reported in 2002 (Kairo et al. 2002).

The extent of mangrove cover in Kenya has been estimated on multiple occasions with variable values reported (Table 4). Earlier estimates of 1981 reported 52,000 ha (Doute et al. 1981), while the most recent cover of 2010 determined from Landsat satellite imagery estimated the total mangrove coverage of 45,590 ha (Kirui et al. 2013). The methods used in estimating the cover and possible loss of mangroves due to increased exploitation rates are the likely reasons for this variability in the estimated mangrove cover over years. 
Studies at single sites have shown reduction in coverage and quality depicting a scenario where Kenyan mangroves are conforming to the global trends of declining cover. Comparison of mangrove cover in Lamu-Kiunga area in 1995 and 2014 shows a decline in cover (Okello et al. 2015). However, the overall loss of mangrove cover in Lamu-Kiunga was highest between 2000 and 2005 when 2,046.17 ha of mangroves was lost. The current mangrove cover in the NRT-Coast conservancy areas within Pate and Kiunga were estimated at 11,277 ha, which represents a $22.6 \%$ cover loss over 19 years (Okello et al. 2015).

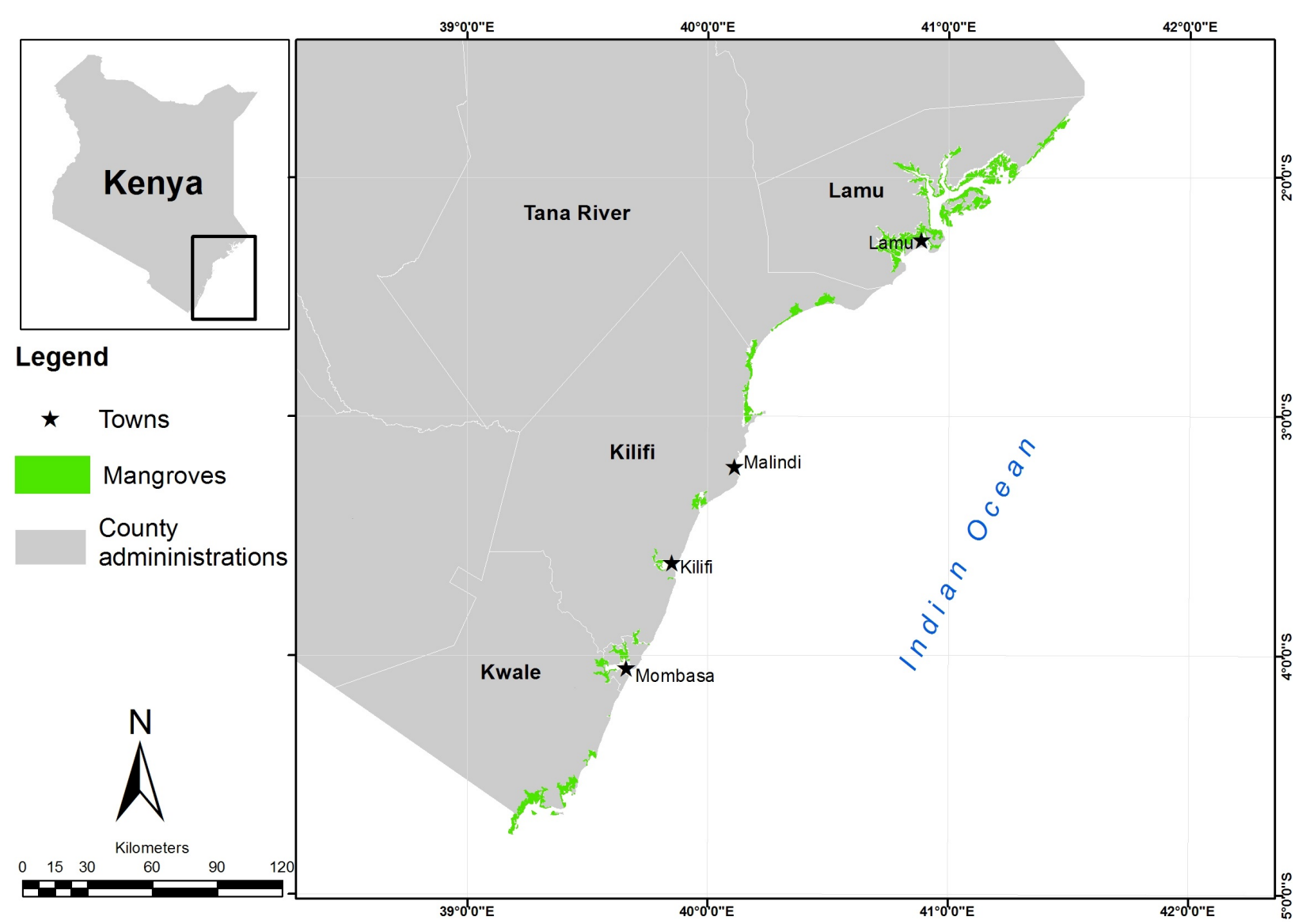

Figure 7: Spatial distribution of mangroves along the Kenyan coast

\section{Mangrove diversity}

The global distribution of mangroves indicates a tropical dominance with major latitudinal limits relating best to major ocean currents. There are 9 orders, 20 families, 27 genera and roughly 70 species of mangroves occupying a total estimated area of $181,000 \mathrm{~km}^{2}$ (Spalding et al, 1997). However, the exact number of species is still under discussion and ranges from 50 to 70 according to different classifications. The highest species diversity is found in Asia, followed by eastern Africa (Maiti et al. 2013). 
Table 4: National level mangrove area estimates in Kenya from 1931 to 2010

\begin{tabular}{|c|c|c|c|}
\hline Year & Area (ha) & Methodology and remarks & Source \\
\hline 1931 & 64,427 & $\begin{array}{l}\text { Secondary reference, no primary } \\
\text { source provided }\end{array}$ & FAO 1993 \\
\hline 1971 & 50,000 & $\begin{array}{l}\text { Rough estimate. Secondary reference, } \\
\text { no primary source provided }\end{array}$ & FAO 1993 \\
\hline 1980 & 45,000 & Estimation and updating & FAO and UNEP 1981 \\
\hline 1981 & 54,325 & Remote sensing & Doute et al. 1981 \\
\hline 1983 & 62,380 & Cited in: FAO 1991 & $\begin{array}{l}\text { Forest Department Kenya } \\
1983\end{array}$ \\
\hline 1988 & 96,100 & Map analysis & Spalding et al. 1997 \\
\hline 1989 & 63,783 & $\begin{array}{l}\text { Secondary reference, the "Year" is the } \\
\text { publication year }\end{array}$ & FAO 1991 \\
\hline 1992 & 58,700 & The "Year" is the publication year & Semesi 1992 \\
\hline 1995 & 52,980 & Remote sensing & Gang 1995 \\
\hline 1996 & 57,300 & $\begin{array}{l}\text { Secondary reference, no primary } \\
\text { source provided }\end{array}$ & $\begin{array}{l}\text { WRI, UNEP, UNDP, The } \\
\text { World Bank } 1996\end{array}$ \\
\hline & & The "Year" is the publication year & \\
\hline 2000 & 61,000 & $\begin{array}{l}\text { Secondary reference, no primary } \\
\text { source provided. The "Year" is the } \\
\text { publication year }\end{array}$ & $\begin{array}{l}\text { World Resources Institute } \\
2000\end{array}$ \\
\hline 2010 & 45,590 & Landsat satellite imagery & Kirui et al. 2011 \\
\hline
\end{tabular}

Source: FAO, UNEP 1981

Mangrove species composition in Lamu-Kiunga area is diverse with eight of the nine species known in Kenya present (Table 5; Weru et al. 2001). The dominant species are Rhizophora mucronata, Ceriops tagal and Avicennia marina (Table 6). Others are Xylocarpus granatum, Xylocarpus molluccensis, Bruguiera gymnorrhiza, Sonneratia alba and Lumnitzera racemosa (Table 5). Worth noting is the presence of large stands of Heriteria littoralis a unique mangrove species mostly found south of Lamu in the Tana River Delta. This species is one of the tallest, and develops broad canopies. It also supports the growth of shrubs that attract elephants to forage in mangrove ecosystems, a unique phenomenon in the coastal region (Samoilys et al. 2011a).

The distribution of mangrove species is significantly influenced by both human and natural factors (Feller et al. 2010). The zonation pattern of mangroves is, for example, dynamically influenced by the level of inundation and salt concentration in the surrounding environment (Van Speybroeck 1992). Studies of oil spills (anthropogenic) in the Caribbean have shown that mangroves exhibit increased mutation rates and long (approximately 20 years) recovery times may be required after repeated 
exposure (Burns et al. 1993, Klekowski et al. 1994) thus reducing their genetic vigor through death and retardation. Such impacts are likely to happen upon full operation of the Lamu Port and consequently change the species distribution highlighted in Table 6.

Table 5: Mangrove species of Lamu-Kiunga region

\begin{tabular}{llll} 
Family & Species & Local name & Geographical \\
& & & range \\
\hline Avicenniaceae & Avicennia marina (Forskål) Vierh. & Mchu & WIO, Red Sea, A \\
& & & Gulf to W Pacific \\
& & Ocean \\
Rhizophoraceae & Bruguiera gymnorrhiza (L) Lamarck & Muia & Indo-Pacific \\
Rhizophoraceae & Ceriops tagal (Perr) C. B. Robinson & Mkandaa & WIO to W Pacific \\
Rhizophoraceae & Rhizophora mucronata Lamarck & Mkoko & WIO to W Pacific \\
Combretaceae & Lumnitzera racemosa Willd & Kikandaa & WIO to W Pacific \\
Sonneratiaceae & Sonneratia alba J.E. Smith & Mlilana & WIO to W Pacific \\
Meliaceae & Xylocarpus granatum Koenig & Mkomafi & WIO to Central \\
Sterculiaceae & Heritiera littoralis* (L.) Dryander & Msikundazi & Pacific Ocean \\
& & & WIO to Central
\end{tabular}

${ }^{\text {a }}$ Found in Tana Delta, south of Lamu

Adapted from Samoilys et al., 2011a

Table 6: Species distribution and cover within the Kiunga Marine National Reserve

\begin{tabular}{lrr} 
Species & Area (Ha) & Coverage (\%) \\
\hline Ceriops type forests & 2465.77 & 15.38 \\
Mixed Ceriops types & 445.05 & 2.78 \\
Ceriops-Rhizophora type & 1264.22 & 7.88 \\
Avicennia type & 2673.17 & 16.67 \\
Mixed Avicennia type & 560.97 & 3.50 \\
Rhizophora & 3871.11 & 24.14 \\
Mixed Rhizophora type & 3646.45 & 22.74 \\
Sonneratia-Rhizophora type & 507.98 & 3.17 \\
Sonneratia type & 601.22 & 3.75 \\
\hline Total area & $\mathbf{1 6 0 3 5 . 9 4}$ & $\mathbf{1 0 0}$ \\
\hline
\end{tabular}

Source: Kairo et al. 2002

\section{Mangrove zonation}

Mangroves are typically distributed from mean sea level to highest spring tide, and perhaps the most conspicuous feature at first glance is the sequential zonation of tree species perpendicular to the shore (Smith, 1992). Mangrove zonation in Kenya, has been typically considered to follow similar pattern, developing from the sea and progressively extending to the land as follows: Sonneratia alba, 
Rhizophora mucronata, Bruguiera gymnorrhiza, Ceriops tagal, Avicennia marina, Xylocarpus granatum, Lumnitzera racemosa (Wild) and Heritiera littoralis, which shows a lot of variability (Figure 8; Kairo 2001, Dahdouh-Guebas et al. 2002). Bruguiera gymnorrhiza does not form a distinct zonation but occurs interspersed with Rhizophora and Ceriops while Avicennia shows a disjointed and distinct zonation displayed at two zones, one landward and one seaward. Generally, other species may be found growing within mangrove forests and the zonation pattern may vary depending on the biophysical characteristics of the location as well as human interference.

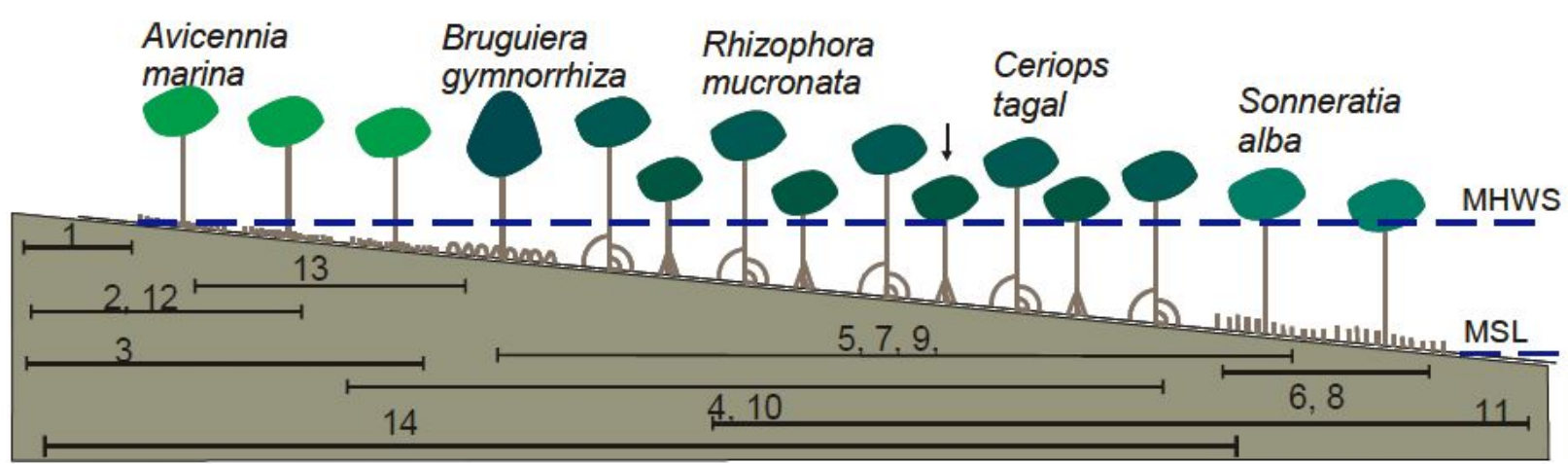

Adapted from Lang'at and Kairo 2013

Figure 8: Zonation of mangroves along the land-sea interface 


\section{Biodiversity of pelagic habitats}

\section{Introduction}

Pelagic habitats are of conservation importance as they are used by migratory species such as whales, sharks and sea turtles. In contrast to the shallow coastal habitats, pelagic environments over deep water are less productive and less diverse, but nevertheless support important offshore commercial fisheries (FAO 2009). Some high value species of conservation importance occur in these habitats but are not typically restricted to them, and these are detailed below. Key threats to these habitats include overexploitation through commercial and artisanal fishing and a high potential for occurrence of alien or invasive species. Several high and medium biodiversity value fish species may occur, including a number of threatened mammals and elasmobranchs (sharks and rays).

\section{Marine Mammals and Turtles}

Dugongs, turtles, whales and dolphin occur in the Lamu archipelago (Table 7). Of these, one species is Critically Endangered, three are Endangered, three are Vulnerable and one Near Threatened, under the IUCN Red List categories (Table 7). Populations of dugongs (Dugong dugon) are known to have occurred in the Pate Island-Kiunga area especially in the seagrass beds around the Ziwaiyu coral reef system. However, recent sightings are very rare and the species is likely to have become extinct. In addition, the seagrass beds around the islands are feeding grounds for green turtles (Chelonia mydas) while the Islands of Manda and Lamu provide nesting beaches for four endangered turtles: hawksbill (Eretmochelys imbracata), green (C. myda), loggerhead (Carretta caretta) and leatherback (Dermochelys coriacea).

Table 7: IUCN categories of marine mammals sighted in Pate Island - Kiunga area

\begin{tabular}{|l|l|l|}
\hline \multicolumn{2}{|l|}{ Common Name } & \multicolumn{2}{l|}{ IUCN Red List category } \\
\hline Dugongs & \multicolumn{2}{|l|}{ Dugong dugon } \\
\hline Dugongs & \multicolumn{2}{|l|}{ Vulnerable A2bcd } \\
\hline Turtles & Chelonia mydas & Endangered A2bd \\
\hline Green turtles & Eretmochelys imbricata & Critically Endangered A2bd \\
\hline Hawksbill & Caretta caretta & Endangered A1abd \\
\hline Loggerhead & Dermochelys coriacea & Vulnerable A2bd \\
\hline Leatherback & & \\
\hline Whales & Megaptera novaeangliae & Least Concern \\
\hline Humpback whale & Balaenoptera borealis & Endangered A1ad \\
\hline Sei whale & Physeter macrocephalus & Vulnerable A1d \\
\hline Sperm whale & Globicephala macrorhynchus & Data Deficient \\
\hline Short-finned pilot whale & \\
\hline Dolphin & & Near Threatened \\
\hline $\begin{array}{l}\text { Indo-Pacific humpbacked } \\
\text { dolphin }\end{array}$ & Sousa chinensis & \\
\hline
\end{tabular}




\begin{tabular}{|l|l|l|}
\hline Common Name & Species & IUCN Red List category \\
\hline Bottle dolphin & Tursiops truncatus & Least Concern \\
\hline Pantropical spotted & Stenella attenuata & Least Concern \\
\hline Spinner dolphin & Stenella longirostris & Data Deficient \\
\hline Stripped dolphin & Stenella coeruleoalba & Data Deficient \\
\hline $\begin{array}{l}\text { Short-beaked common } \\
\text { dolphin }\end{array}$ & Delphinus delphis & Least Concern \\
\hline
\end{tabular}

Adapted from Samoilys et al. 2011a, 2015

Local resorts and local communities have reported the presence of whales and dolphins in the Pate area. Humpback (Megaptera novaengliae), sei (Balaenoptera borealis), sperm (Physeter microcephalus) and pilot (Globicephala macrorhynchus) whales have been sighted in the region and are known to breed and feed in the offshore waters (Obura et al. 2012). The whale population in this area is vulnerable due to their rarity and threats of the drifting gillnet fishery. In 1996 a total of 500 dolphins were observed in areas outlying Manda and Pate Islands (Wamukoya et al. 1996). Most of the dolphins are relatively common during the Northeast monsoon with the common threat being incidental capture by the gillnet fishery.

\section{Sharks and rays}

There are 137 species of sharks and rays in the WIO region, of which 15 are endemic to the region (Smith and Heemstra 1991). The highest diversity of sharks and rays has been recorded in Mozambique's waters with 73 sharks and 35 rays (Samoilys et al. 2015). In Kenya, sharks are targeted for shark fins and liver oil. Shark fishing is a traditional practice in the Pate Island-Kiunga area, which has operated for centuries, though the decline in catch rates has been very high: estimated at $85 \%$ over the past 40 years (Samoilys and Kanyange 2008, Samoilys et al. 2015). Six shark species and nine ray species have been confirmed as fished and sighted in the Pate Island- Kiunga area (Table 8), but this list is far from exhaustive. Little is known about the status of these species and their occurrence in Kenyan waters.

Table 8: IUCN categories of sharks and rays fished and sighted in Pate Island-Kiunga area

\begin{tabular}{|l|l|l|}
\hline Species & Common name & IUCN Red list category \\
\hline Sharks & & \\
\hline Rhincodon typus & Whale shark & Vulnerable A2bd+3d \\
\hline Carcharhinus melanopterus & Blacktip reef shark & Near Threatened \\
\hline Triaenodon obesus & Whitetip reef shark & Near Threatened \\
\hline Galeocerdo cuvier & Tiger shark & Near Threatened \\
\hline Sphyrna lewini & Scalloped hammerhead & Endangered A2bd $+4 \mathrm{bd}$ \\
\hline
\end{tabular}




\begin{tabular}{|l|l|l|}
\hline Species & Common name & IUCN Red list category \\
\hline Sphyrna mokarran & Great hammerhead & Endangered A2bd+4bd \\
\hline Rays & & \\
\hline Manta birostris & Giant manta ray & Vulnerable A2abd+3bd+4abd \\
\hline Aetobatus narinari & Giant guitarfish & Vulnerable A2d+3d+4d \\
\hline Taeniura lymma & Spotted eagle ray & Near Threatened \\
\hline Taeniurops meyeni & Ribbontailed sting ray & Near Threatened \\
\hline Neotrygon kuhlii & Blotched fantail ray & Vulnerable A2ad+3d+4ad \\
\hline Himantura uarnak & Bluespotted stingray & Data Deficient \\
\hline Torpedo fuscomaculata & Honeycomb Stingray & Vulnerable A2bd+3bd+4bd \\
\hline
\end{tabular}




\section{Introduction}

Coral reefs, mangroves and seagrass as well as the pelagic habitats are vulnerable coastal habitats that provide economic goods and services, contributing to the livelihoods and food security of communities living in the Lamu-Kiunga area. Coral reefs protect the shoreline from erosion waves and storm surges, both of which are likely to increase in the face of sea-level rise. Coral reefs are sources of livelihoods of local people through subsistence and semi-commercial fishing, tourism and recreational activities (Obura et al. 2012, Conservation International 2008).

The presence and abundance of seagrasses are regarded as indicators of the overall environmental quality of the coastal zone (Terrados and Borum 2004). Seagrass provide habitats for a wide range of organisms and also fix carbon dioxide using light energy, thus promoting local biodiversity and biological productivity. Seagrass meadows produce an array of goods and services including providing habitat for finfish and traps sediment particles to enhance water-quality, maintain the biodiversity and shoreline protection.

Mangroves provide valuable ecosystem services including habitat functions such as breeding, spawning and nursery grounds for commercial fish; provision of timber, fuel wood, and charcoal; regulation of floods, storms and erosion; and prevention of saltwater intrusion.

A range of environmental threats occur in the Lamu-Kiunga area. They include increasing population growth, high poverty levels, deforestation of mangroves, clay mining for pottery, unclear land ownership and insecurity that has decimated opportunities in tourism, overfishing due to an increasing population size and destructive fishing, unsustainable and illegal fishing particularly the use of beach seines and poaching of turtles (Samoilys et al. 2011a). Another pending threat to marine habitats is the Lamu Port and Lamu-Southern Sudan-Ethiopia Transport Corridor (LAPSSET project) that is likely to lead to oil spills, urbanization and industrialization of Lamu. Numerous existing oceanrelated activities occurring in the Lamu-Kiunga area are already threatening the marine and coastal habitats and resources. These activities include artisanal fisheries, offshore commercial fisheries including those by foreign fishing vessels in Kenya's Exclusive Economic Zone (EEZ), mangrove harvesting, boat making, coastal tourism, offshore oil and gas exploration and port development. These ocean-related activities, combined with the effects of global warming and the environmental threats mentioned above can affect marine habitats and communities in a variety of ways. Mangroves continuously face both natural and anthropogenic threats and pressure (FAO 2007), with their global coverage reducing by 23\% within a span of two decades from 1990 to 2010 (Spalding et al. 2010). An ever-growing pressure on coral reef resources poses a great threat to the survival and conservation of coral reef habitats globally (Ginsburg et al. 1994, Obura et al. 1998) and this is true of the northern Kenya coast. Fishing has impacts on habitat and on the diversity, structure and productivity of benthic communities and their associated fishery resources, including finfish and crustaceans. It is one of the main activity affecting marine habitats and communities in this northern region and is discussed further below. 


\section{Use of fish and threats to fisheries}

The fisheries of Lamu-Kiunga are the primary source of livelihood of $70 \%$ to $75 \%$ of seascape residents either directly or indirectly (Ochiewo et al. 2009). These fisheries are threatened by the use of destructive and illegal fishing gears such as beach seines and ever-increasing fishing effort due to very limited alternatives, which have resulted in overexploitation of fishery stocks. A number of factors instigate overexploitation in these fisheries:

- Inadequate enforcement of legislation (State Department of Fisheries regulations and Kenya Wildlife Service regulations in the Reserve)

- High population growth rates, which in the absence of alternative livelihoods increases the number of fishers and consequently fishing pressure

- High poverty levels and poverty traps limit the possibilities for schooling, which maintains low literacy levels and competencies, which limits possibilities to develop alternative livelihoods outside fisheries

- Inadequate community involvement in resource management and inadequate sensitization and awareness on the importance of biodiversity as a basis for their livelihoods

- Increasing market demand for fish and shellfish commodities, while improved prices are a benefit to fisheries, improved access to market can increase pressure on resources

\section{Resource utilization and extraction}

The number of fishers in Lamu County is about 3,100 and is projected to increase at a rate of 127 fishers/year (Figure 9). These fishers use different fishing gears and vessels. Common gears include gill nets, handlines, beach seines, longlines, fence traps and basket traps. Long lines with drop hooks are by far the most deployed gear in Lamu County representing 60\% of all gears (Figure 10). 881 monofilaments gillnet and 97 beach seines, both illegal, are in use in the area (Figure 11). Monofilament nets have increased enormously since 2008, though beach seines have declined (Figure 11). No records of spearguns, the other illegal gear commonly used further south, were found in Lamu during the recent frame survey (GoK, 2012). Beach seine use is highest in Lamu County accounting for $45 \%$ when compared to other coastal counties (GoK, 2012) despite their damaging impacts on breeding and nursery grounds of fish. The gear is associated with high by-catch, which includes catching large quantities of juvenile fish (68\%) and turtles (Mangi and Roberts 2006). 


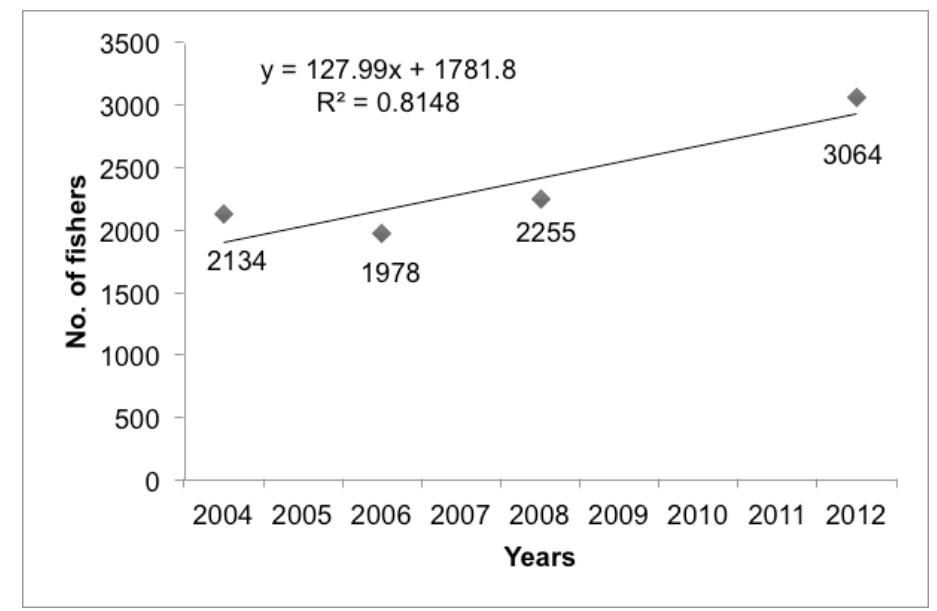

Source: GoK 2012

Figure 9: Trends in the number of fishers in Lamu County

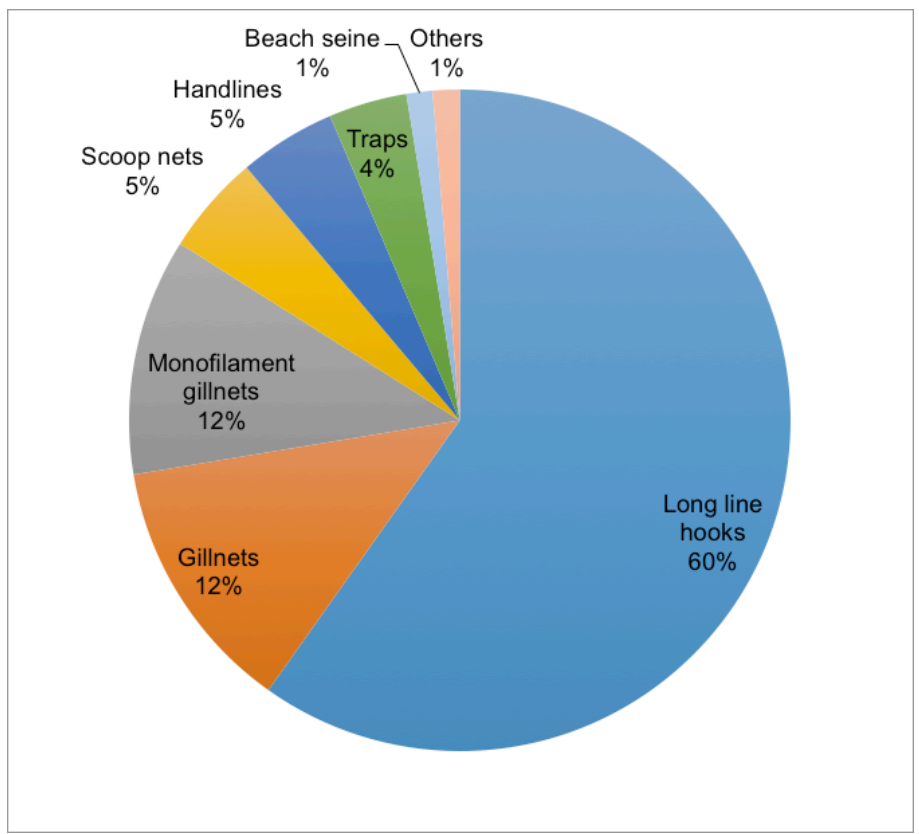

Source: GoK, 2012

Figure 10: Distribution of fishing gears in Lamu County. "Other" gears includes prawn seine nets (0.9\%), trolling lines $(0.2 \%)$, trammel nets $(0.1 \%)$ and cast nets $(0.1 \%)$. 


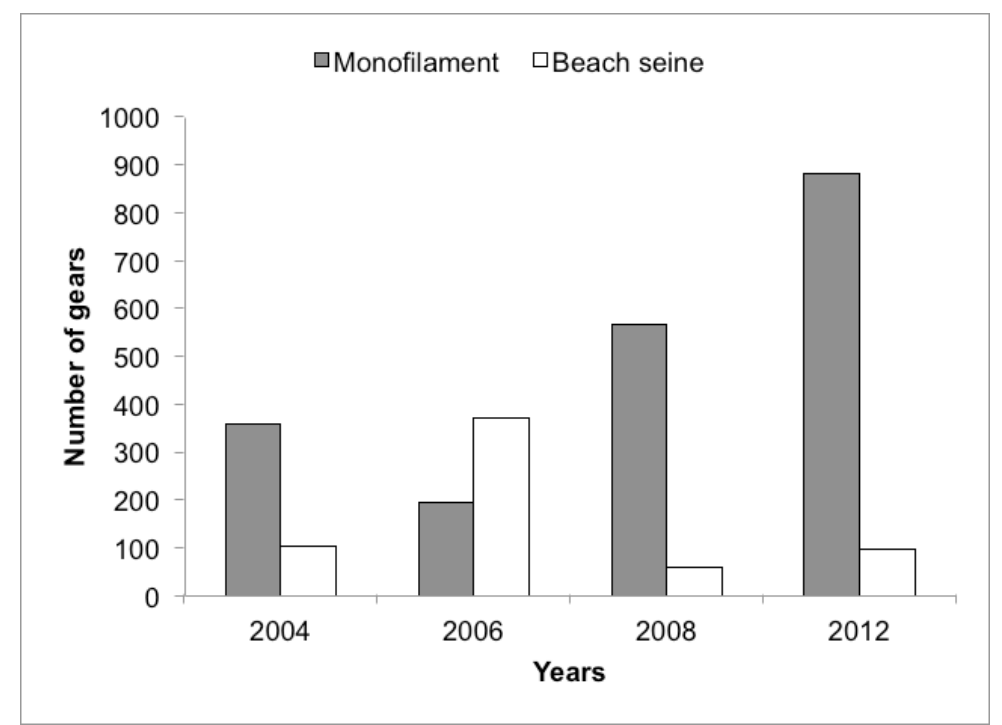

Source: GoK, 2012

Figure 11: Number of illegal gears in use in Lamu County.

\section{Trends in fish catches}

Fish landings from 2000 to 2008 ranged between 1,500 and 2,000 metric tons per year, of which about $40 \%$ of the catch was sold to areas outside Lamu County (Ochiewo et al. 2009). Most fishing activities are undertaken during the Northeast monsoon when the sea is calm (Wanyonyi et al. 2011). In general, the catches have been relatively stable from 2001 to 2008 ranging from 9-14.3 kg/fisher/day with a mean of approximately $10.2 \mathrm{~kg} /$ fisher/day. The catch per unit effort (CPUE) from 2001 to 2007 varied considerably across the fishing gears with spearguns recording the lowest mean CPUE (Table 10). The average daily income derived from fishing is Ksh. $398(\sim 4)$ but income varies between villages. Kiunga records higher mean incomes of Ksh. 580 than Mkokoni at Ksh. 200 (Ochiewo et al. 2009). Notable fisheries that are more valuable in the Lamu-Kiunga area include the lobster and crab fisheries. Lobsters and crabs are mainly fished in Kizingitini, Faza, Kiwayu and Kiunga (Ochiewo et al. 2009; Maina and Samoilys 2011).

Table 9: Mean catch per unit effort from 2001-2007 of gears used in Lamu County

\begin{tabular}{ll}
\hline Gear & Mean CPUE (kg/fisher/day) \\
\hline Speargun & 3.2 \\
Gillnet (jarife) & 7.9 \\
Handline & 8.6 \\
Beach seine & 9.8 \\
Gillnet (nyavu) & 10.7 \\
Basket trap & 11.2 \\
Fence trap & 15.7 \\
\hline Source Ochiewo et al. 2009 &
\end{tabular}

Fish species taken by the local artisanal fisheries comprise rabbitfish (Siganidae), sweetlips (Haemulidae), mullet (Mugillidae), surgeonfish (Acanthuridae), milkfish (Chanidae), emperors (Lutjanidae), parrotfish (Scaridae), snappers (Lutjanidae), kingfish (Scombridae), eels, sharks and rays 
(Samoilys, 1988; Obura, 1998; Weru et al., 2001, Samoilys et al., 2011a). Catfish, cavalla jacks, mackerel, barracuda, mullets, queen fish, sailfish, tuna, prawns, crabs, sardines, oysters and octopus are also captured. Sharks are targeted for their fins and liver oil.

\section{Fisheries issues}

The use of the illegal beach seine in sites such as Faza and Kizingitini is exacerbated by the inability of the local fishermen to purchase appropriate fishing gears to venture offshore. Beach seines and monofilament nets are illegal due to their destructive impacts and have been a major cause of conflict between local fishermen and the State Department of Fisheries and conservation agencies (Ochiewo et al. 2009). They threaten the sustainability of the fisheries resources especially since the gears are deployed in the Kiunga Marine National Reserve. Other fisheries-related issues include overexploitation, uncontrolled development, pollution and climate change.

\section{Lamu Port and Lamu-Southern Sudan-Ethiopia Transport Corridor (LAPSSET) project}

The $\$ 24.5$ billion LAPSSET project is poised to severely impact artisanal fishing and conservation areas in the Lamu-Kiunga seascape. The construction and operationalization of the 32 berth port will interrupt the livelihoods of the fishers working in the highly productive fishing areas of Kizingitini and Faza by restricting access to fishing grounds, increase the risks of injury and death for lobster divers as well as increase boat traffic which is likely to increase the risk of accidents at sea. The dredging will also destroy coral reefs and mangrove habitats that represent important biodiversity areas as well as provide breeding and feeding grounds for fish. In the long-term the dredging activities will limit the capacity of fish regeneration along the channel.

With port development, competition for prime land surrounding the port area is projected to increase leading to loss of beach access routes by fishers. A potential impact of oil spills due to shipping activities will cause destruction of local marine species and the ecosystem through pollution and physical processed, depletion of fish stocks and thus damage the fishing industry (Valarie 2014). Spillage and dumping of industrial chemicals and refuse will contribute to the introduction of alien marine species. Port management routines should therefore include ballast water management plans to abate introduction of invasive marine species. The outcome of this will be the loss of rare species in the area such as the endangered Dugong, turtles and key fish species.

\section{Threats to seagrass beds}

Growing coastal populations coupled with human disturbance such as pollution, eutrophication and sedimentation due to port construction, fishing activities and collection of mollusks for the tourist trade, pose a big threat to seagrass beds. These human-related activities significantly reduce water clarity, which affects the depth at which seagrasses can grow. High abundances of sea urchins that increase the predation on seagrass are another threat to the recovery seagrass. 


\section{Threats to mangroves}

Despite the accumulated benefits from mangrove ecosystems, threats to mangrove forest have been on the increase from both anthropogenic as well as natural pressures (Abuodha and Kairo, 2001) as witnessed by the ever decreasing trends in their global coverage (Spalding et al., 2010). The loss of mangroves for pond aquaculture (i.e. prawn farming) is considered one of the largest threats to mangrove forests worldwide (Alongi, 2002). However, natural factors cannot be ruled out, for instance in the Sunderbans of Bangladesh, nearly $20 \%$ of Heritiera fomes trees were severely affected by 'top dying' disease that slowly kills the trees by moving from leaves, branches and twigs to the main stem (Spalding et al., 2010).

Threats to Kenyan mangroves and by extension to those in the Lamu-Kiunga area include high rates of conversion for alternative uses particularly for the salt extraction, and most recently from rapid mega structure construction such as the Lamu Port Southern Sudan-Ethiopia Transport (LAPSSET) infrastructure as well as poor and selective enforcement of policies (NEMA, 2013).

More than 10,310 ha or $20 \%$ of the total mangrove area in Kenya have been lost (Kairo and Abuodha 2001) in the past through:

a) Dredging - where up to 100ha was lost in Lamu;

b) Conversion - 100 ha of mangrove converted for mariculture at Ngomeni,

c) Fuel wood exploitation, e.g., in Gazi where 100ha was lost;

d) clearance - about 10,000ha of mangrove cleared for salt extraction between Ngomeni and Karawa;

e) Oil spill - where 10 ha of mangrove were lost in Makupa

\section{Community utilization}

Mangroves are heavily used traditionally and commercially worldwide (Kathiresan and Bingham, 2001). They provide a resource base that is ecologically, economically and socially important to people, either directly or indirectly. Economically, mangroves forest serves as an avenue for important products and by-products to the coastal population as well as to the national economies (Kairo 2001). In the East Africa region, mangroves have historically played important economic roles notably: they formed part of the slave and ivory trade in the $9^{\text {th }}$ century (Rawlins 1957). By then, house construction in the Arab countries depended on the poles from the East African coast, particularly from LamuKiunga. By the beginning of the $20^{\text {th }}$ century, Kenya was exporting an annual average of 24,150 scores of mangrove poles from Lamu, equivalent to 483,000 poles per year (Grant 1938). To date, local communities within the Lamu-Kiunga area continue to thrive on the economics of mangrove products for trade, boat making as well as for the sustenance of the ever growing construction industry (Abuodha and Kairo 2001, Samoilys et al. 2011a, Maina et al. 2011).

Utilization of mangroves by coastal communities of Kenya is species-specific. Rhizophora mucronata and Ceriops tagal are constantly being targeted for construction of houses while Sonneratia alba is used in boat construction. The preferential cutting of certain mangrove species may favor other species such as Avicennia marina and thus affect species composition, ecosystem function and species richness (Kairo 2001). 


\section{LAPSSET project}

Port construction will involve dredging of shallow inland channels and logging and clearing of shoreline-stabilizing mangrove forests. The excavation process and siltation caused by dredging activities will dramatically reduce fish breeding sites and the cover of mangrove forests in the area. Many poor locals will therefore lose their primary source of livelihood - fishing and/or mangrove harvesting. The impact on mangroves is imminent but further assessment is required to ascertain the severity of the damage. More importantly, mangrove conservation should be considered in land use planning of Lamu County.

\section{Use of fishes and threats to the pelagic marine system}

There is little information on the nature of the ecosystem services in the pelagic marine environment of the Lamu-Kiunga seascape. Nevertheless, pelagic ecosystems generally offer services such as energy development, commercial fishing, shipping lanes and recreational uses (Rogers et al. 2014). The pelagic marine system of Lamu-Kiunga hosts invertebrates (e.g. squid), fish (e.g. tunas, sharks and rays), large marine mammals (e.g. whales, dolphins), sea turtles and sea birds. Planktonic organisms, phytoplankton and zooplankton, are abundant but no detailed studies from this area are available. These organisms are vital elements of the food chain and for supporting rich offshore fisheries.

Operations of the port will necessitate closing traditional fishing grounds used by a significant number of fishermen who depend on the waters for their livelihood. It is likely that they will be forced to abandon the safer and more sheltered fishing grounds and venture in the high sea or increase fishing pressure on other fishing grounds. Moreover, port construction will change the water flow around Manda and Lamu islands that may result in silting of the key channel used in transport and communication from Lamu to the north. Clearly, if oil and gas extraction and excavation proceed, marine traffic and pollution of these waters is inevitable. 


\section{Opportunities for improved management}

\section{Introduction}

The Driving Force-Pressure-State-Impact-Response framework (DPSIR) provides an overall mechanism for assessing environmental problems, thereby defining potential opportunities. The Driving forces exert Pressures, leading to changes in the State of the environment, which then lead to Impacts on ecosystem goods and services that will in turn require a societal Response. The DPSIR analysis of the shallow and pelagic habitats of the Lamu-Kiunga seascape are summarized in Table 9.

In response to the impacts of natural and anthropogenic events on marine ecosystems, several institutions have engaged in providing solutions to the pending threats. The principal institutions with a mandate of management of marine and coastal resources comprise government agencies, community groups and NGOs.

Enactment of a wide range of national, coastal and environmental legislation is part of policy response to the pending problems. Several pieces of legislation governing management of the coastal and marine environment include Environmental Management and Coordination Act, Fisheries Act, Wildlife Conservation and Management Act, Forests Act, Agriculture, Fisheries and Food Authority Act, The Land Act, The Physical Planning Act, The Urban Areas and Cities Act, The Devolved Government Act, Kenya Maritime Authority Act, Maritime Zones Act and Continental Shelf Act (Samoilys et al. 2011c). These regulations have been pivotal in the management of resources along the Kenyan coast and provide an excellent base for future marine spatial planning and integrated coastal zone management. Worth noting is the adoption of co-management structures for fisheries through the Beach Management Units, enacted in 2007 and under the mandate of the State Department of Fisheries, to improve resource management. Whilst efforts have increased community participation in resource management, a number of barriers have reduced their effectiveness, notably the inability to enforce by-laws and strong traditional and cultural attitudes. More is still required, especially with regards to enabling communities to be more resilient to the pending threats, particularly of climate change. 
Table 10: DPSIR analysis of environmental problems affecting biodiversity in the shallow and pelagic marine habitats of the Lamu-Kiunga area

\begin{tabular}{|c|c|c|c|c|c|}
\hline Habitat & Drivers & Pressures & State & Impact & Response \\
\hline 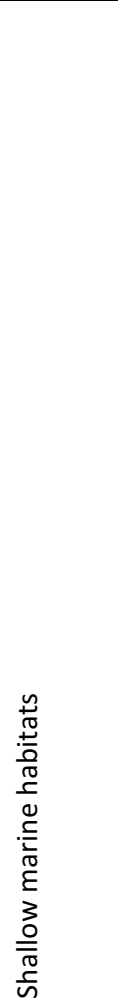 & $\begin{array}{l}\text { - Climate change and variability } \\
\text { (ENSO, water temperature, } \\
\text { ocean acidification) } \\
\text { - Population growth } \\
\text { - Poor education and illiteracy } \\
\text { - Insecurity decimating } \\
\text { opportunities in tourism } \\
\text { - Increasing poverty } \\
\text { - Destructive fishing } \\
\text { techniques } \\
\text { - Land use, river sediment load } \\
\text { and eutrophication } \\
\text { - Introduction exotic species } \\
\text { - Rising demand for marine } \\
\text { commodities } \\
\text { - LAPSSET: opening African } \\
\text { hinterland, development of } \\
\text { Lamu port and shipping }\end{array}$ & $\begin{array}{l}\text { - Fishing pressure } \\
\text { destructive fishing } \\
\text { techniques } \\
\text { - Temperature stress causing } \\
\text { coral bleaching } \\
\text { - Mangrove overuse } \\
\text { Pollution and turbidity } \\
\text { - Harmful algal blooms and } \\
\text { disease } \\
\text { Potential oil spills } \\
\text { industrialization in Lamu }\end{array}$ & $\begin{array}{l}\text { - Damaged benthic habitats } \\
\text { from bottom-contacting } \\
\text { fishing gears } \\
\text { - Declining cover of hard coral } \\
\text { and mangroves } \\
\text { - Declining populations of } \\
\text { fishery stocks } \\
\text { - Coral mortality } \\
\text { - Increased coral diseases } \\
\text { - Increased algal cover } \\
\text { - Inadequate scientific } \\
\text { information on state of } \\
\text { seagrass beds }\end{array}$ & $\begin{array}{l}\text { - Reduced fish catch and } \\
\text { benefits from fisheries } \\
\text { - Reduced income from } \\
\text { tourism } \\
\text { - Reduced benefits from } \\
\text { other ecosystem } \\
\text { services including } \\
\text { ecological productivity } \\
\text { from high biodiversity } \\
\text { - Conflict between } \\
\text { fishers and other reef } \\
\text { users } \\
\text { - Conflict between } \\
\text { residents/local } \\
\text { communities and oil } \\
\text { and gas business } \\
\text { - Loss of endemic, rare } \\
\text { and threatened species } \\
\text { (corals, fin-fish, sharks, } \\
\text { dugong) }\end{array}$ & $\begin{array}{l}\text { - Improve compliance to } \\
\text { fisheries and National } \\
\text { Reserve regulations } \\
\text { - Improve compliance } \\
\text { with biodiversity } \\
\text { conservation policies } \\
\text { - Implement effective } \\
\text { regulations for port } \\
\text { and shipping industries } \\
\text { - Plan land use of Lamu } \\
\text { county } \\
\text { - Develop tourism } \\
\text { - Support marine } \\
\text { conservancies or } \\
\text { locally-managed } \\
\text { marine areas (LMMAs) } \\
\text { Build marine resource } \\
\text { management capacity } \\
\text { in fishing communities }\end{array}$ \\
\hline
\end{tabular}




\begin{tabular}{|c|c|c|c|c|c|}
\hline Habitat & Drivers & Pressures & State & Impact & Response \\
\hline 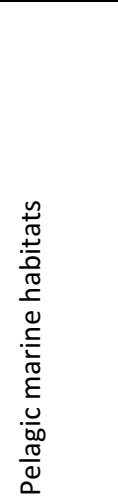 & $\begin{array}{l}\text { - Climate change and } \\
\text { variability }\left(\mathrm{CO}_{2}, \mathrm{ENSO}\right) \\
\text { - Rising demand for marine } \\
\text { commodities } \\
\text { - Introduction modern and } \\
\text { foreign fishing equipment } \\
\text { - Introduction exotic species } \\
\text { - LAPSSET, opening up African } \\
\text { hinterland } \\
\text { - Inadequate enforcement }\end{array}$ & $\begin{array}{l}\text { Ocean acidification }\left(\mathrm{CO}_{2}\right) \\
\text { Fishing pressure } \\
\text { Destructive fishing } \\
\text { techniques (by-catch } \\
\text { mortality) } \\
\text { Pressure marine shipping } \\
\text { lanes } \\
\text { Oil spills } \\
\text { Illegal Unregulated and } \\
\text { Unreported (IUU) fishing in } \\
\text { EEZ waters }\end{array}$ & $\begin{array}{l}\text { - Reduced marine productivity } \\
\text { and food webs (acidification) } \\
\text { - Reduced stocks of } \\
\text { commercial fish species } \\
\text { - Reduced populations of } \\
\text { protected marine fauna (e.g. } \\
\text { sharks, rays, whales, turtles) } \\
\text { - Inadequate scientific } \\
\text { information on pelagic } \\
\text { environments }\end{array}$ & $\begin{array}{l}\text { - Reduced benefits } \\
\text { from fisheries } \\
\text { - Reduction in the } \\
\text { provisioning of other } \\
\text { ecosystem services } \\
\text { such as biodiversity } \\
\text { - Poor compliance to } \\
\text { international } \\
\text { conventions }\end{array}$ & $\begin{array}{l}\text { - Support acquisition } \\
\text { of deep sea vessels } \\
\text { - Improve compliance } \\
\text { biodiversity } \\
\text { conservation and } \\
\text { pollution regulations }\end{array}$ \\
\hline
\end{tabular}




\section{Government institutions}

\section{State Department of Fisheries}

State Department of Fisheries (SDF) is the management body mandated to provide for the exploration, exploitation, utilization, management, development and conservation of fisheries resources. SDF in partnership with the private sector has been a key player in strengthening co-management of marine fisheries resources through rolling Beach Management Units (BMUs). They have also been involved in activities geared towards promoting fish quality assurance, value addition and marketing, facilitation of ice production and cold storage at landing sites in Lamu-Kiunga.

\section{Beach Management Units}

The Beach Management Units (BMU) is a co-management institution legally anchored in the BMU regulations of 2007 of the Fisheries Act Cap 378, 2001 and having administrative oversight over a welldefined area of jurisdiction. There are 13 Beach Management Units (BMUs) in Pate Island compared to nine in Kiunga (Table 11). None of the BMUs have a working cold room for fish storage (GoK 2012).

Table 11: List of BMUs in Lamu-Kiunga area

\begin{tabular}{ll}
\hline Pate area & Kiunga area \\
\hline Faza & Mvundeni \\
Pate & Rubu \\
Kizingitini & Kiunga \\
Tchundwa & Ishakani \\
Mtangawanda & Mwambore \\
Mbwajumwali & Chandani \\
Nduweni & Mkokoni \\
Kibaoni & Kiwayu \\
Kiangwe & Ndau \\
Siyu & \\
Magilini & \\
Shanga Ishakani & \\
Shanga Rubu & \\
\hline
\end{tabular}

\section{Kenya Wildlife Service}

The overall mandate of the Kenya Wildlife Service (KWS) is to conserve and manage Kenya's wildlife and enforce related laws and regulations. An Act of Parliament, Cap 376, (revised edition 1985), established KWS. In the north coast region, KWS is involved in the management of Kiunga Marine National Reserve (gazetted 1979), which is situated north of Pate and extends to the Somali border. It is adjacent to the Boni and Dodori National Reserves inland. KWS has the following functions:

a. Sole jurisdiction over national parks

b. Supervisory role in the management of national reserves, local and private sanctuaries, license, control and supervise all wildlife conservation and management activities outside the protected areas

c. Conservation, education and training

d. Wildlife research 


\section{Kenya Marine Fisheries Research Institute}

The Kenya Marine Fisheries Research Institute (KMFRI) is the research body mandated to carry out research on marine and freshwater fisheries, aquatic biology, aquaculture, environmental chemistry, ecological, geological and hydrological studies, as well as chemical and physical oceanography. KMFRI's research mandate is enshrined in article No. 4 of the Science and Technology Act of 1979, Cap 250.

\section{Policy and institutions for management of mangroves}

As a demonstration of policy and management failure, in 1982, the government, through a presidential order, banned further mangrove export due to lack of proper accounting by the Forest Department on wood products leaving the forest (Box 1). This ban however, was not effective as proved by a series of successive forest inventories, notably the $2^{\text {nd }}$ national mangrove survey of 1992/3. This led to a further ban on local mangrove exploitation in 1997 and since then there has been no formal management plan in place.

Under the Forest Act of 2005, the Kenya Forest Service (KFS) is mandated to protect all forests, woodlands and mangrove forests under their jurisdiction. The ratification of the Kenyan constitution in $\mathbf{2 0 1 0}$ gave rise to the federal form of governance else referred to as counties leading to devolution of services including revenue generation. With this, conflicts of interests are bound to emerge in natural resource management within local and national setup. Whereas the latter will be advocating for conservation measures, the former (local government) would be targeting such resource for revenue maximization leaving the future of mangrove ecosystem on the mercy of political goodwill.

Box 1: Chronology of mangrove management from pre-colonial era to postcolonial period

\begin{tabular}{lll|} 
- & $1891 \quad$ Earliest registration \\
- & $1932 \quad$ Gazettement of mangroves \\
- & $1949 / 50 \quad 1^{\text {st }}$ national mangrove survey \\
- & $1965 / 67 \quad$ Survey of Lamu mangroves \\
- & $1981 \quad 2^{\text {nd }}$ survey of Lamu mangroves \\
- & $1982 \quad$ Ban on mangrove exportation \\
- & $1993 / 95 \quad 2^{\text {nd }}$ national mangrove survey \\
- & $1997 \quad$ Ban on local mangrove exploitation \\
- & $1998 / 99 \quad 3^{\text {rd }}$ survey of Lamu mangroves (Kiunga) \\
- Today $\quad$ NO MANAGEMENT PLAN
\end{tabular}

Adapted from Kairo and Dahdouh-Guebas 2004 


\section{Non-government institutions}

\section{Fisheries Cooperatives}

Lamu has some fishermen cooperative societies including the Rasini Fishermen Cooperative Society, Kizingitini Fishermen Cooperative Society, and Kiunga Fishermen Cooperative Society (Ochiewo et al 2009). Establishment of these cooperative is enshrined in the Cooperative Societies Act (CAP 490. The cooperatives face several challenges notably:

- Lack financial resources to provide credit for the members to acquire new fishing equipment.

- Lack of education to fishermen about the benefits of having a platform for bargaining for better prices for fish;

- The need to minimize exploitation by fish dealers; and

- The need to cushion themselves with opportunities for credit that can be very useful during hard seasons.

\section{World Wide Fund}

The WWF, in partnership with KWS, have been involved in programmes geared towards effective management of Kiunga Marine National Reserve (KMNR) for over 15 years, by initiating the implementation of a seascape management approach. WWF is involved in research and monitoring activities on coral reef, fisheries and other marine resources, with an aim of safeguarding biodiversity and the integrity of physical and ecological processes of the marine ecosystem. Other areas include:

- Carrying out education and awareness programmes

- Development of women's livelihood project

- Collaborating with the Ministry of Health and community groups to improve access to health care

- Supporting development of community conservation areas

\section{CORDIO East Africa}

CORDIO East Africa is a regional research-based not-for-profit organization established in 1998, which is focused on marine and coastal ecosystems in the Western Indian Ocean (WIO). CORDIO generates and shares scientifically sound knowledge for developing solutions to the problems and challenges facing coastal and marine environments and people in the WIO.

In northern Kenya CORDIO has been active through the following activities

i) Coral reef research and monitoring in Kiunga Marine National Reserve (since 1998) and around Lamu.

ii) Research on coral reef resilience to climate change

iii) Fisheries research and management projects (lobster fisheries, fish genetics), livelihood opportunities

iv) BMU capacity building in collaboration with the State Department of Fisheries 


\section{Protected Area approaches}

Marine Protected Areas (MPAs) are a well-recognized approach to conserving marine biodiversity while managing fisheries for the benefit of fishers and the wider community. MPAs are established to protect marine species and habitats and are an effective tool for maintenance or restoration of biological diversity and abundance or marine resources as well as for fisheries management, particularly in tropical coral reef ecosystems (Kelleher 1999, IUCN 2004, Govan et al. 2009). MPA is a generic term used to cover nationally-gazetted marine parks and reserves as well as Locally-Managed Marine Areas (LMMAs), also dubbed community conservation areas or conservancies (Kawaka et al. 2015). In Kenya there are nine national marine parks and reserves, established between 1968 and 1995, covering an estimated $10.4 \%$ of territorial waters (Table 12). The parks are no-take zones or area closures where no extraction is allowed at all, and at least since the 1990s has been well enforced (Samoilys and Obura 2011). These national parks have proved effective at restoring fish abundance (McClanahan and Graham 2005, Samoilys et al. in press). However, the reserves are having little impact on fish populations, because the legislation around Reserves, which allows for traditional fishing methods, is not being enforced. Kiunga Marine Reserve, which was established in 1979, is the largest Reserve in Kenya, covering $250 \mathrm{~km}^{2}$ (Table 12) and therefore this poor effectiveness is of considerable concern.

Table 12: Nationally gazetted Marine Protected Areas in Kenya

\begin{tabular}{lllll}
\hline Site & IUCN Category & Size $\mathbf{( k m}^{2} \mathbf{)}$ & Date established & Management type \\
\hline Malindi & II & 6.3 & 1968 & Park \\
Watamu & II & 10 & 1968 & Park \\
Malindi- & $\mathrm{VI}$ & 245 & 1968 & Reserve \\
Watamu & & & & \\
Kisite & $\mathrm{II}$ & 28 & 1978 & Park \\
Mpunguti & $\mathrm{VI}$ & 11 & 1978 & Reserve \\
Kiunga & $\mathrm{VI}$ & 250 & 1979 & Reserve \\
Mombasa & $\mathrm{VI}$ & 200 & 1986 & Reserve \\
Mombasa & $\mathrm{II}$ & 10 & 1986 & Park \\
Diani-Chale & $\mathrm{VI}$ & 75 & 1995 & Reserve \\
\hline Source: IUCN, 2004 & & & &
\end{tabular}

Source: IUCN, 2004

Locally Managed Marine Areas (LMMAs)

The adoption of LMMAs by local fishing communities, primarily though the BMUs, has increased exponentially in Kenya in the last 10 years (Kawaka et al. 2015) with a total of 24 LMMAs established by 2015 (Figure 12). The establishment of LMMAs along the Kenyan coast has been motivated by the need to improve the health of the ecosystem, to reduce overexploitation, livelihood development, eco-tourism and habitat and species protection. They are a spatially-based conservation and management approach that is now well recognized as suitable for shallow coastal habitats with dependent fishing communities (Govan et al. 2009, Rocliffe et al. 2014) such as those of the LamuKiunga area. The formation of community conservancies around Pate Island in 2015 has been led by TNC and NRT-Coast. They are anchored in the Wildlife Conservation and Management Act 2013. They were established to interweave conservation efforts with improving local livelihoods. It is expected 
that the conservation measures will reverse the declining trends in the numbers of marine wildlife, particularly fin-fish as well as valuable macro-invertebrates (e.g. lobster and crab) thus boosting ecotourism projects, which will bring income to the community. The formation of the Kiunga Marine Community Conservancy proposed within the Kiunga Marine National Reserve (KMNR) is designed to support the Reserve and improve the integration of local traditional knowledge on environment with modern science and research.

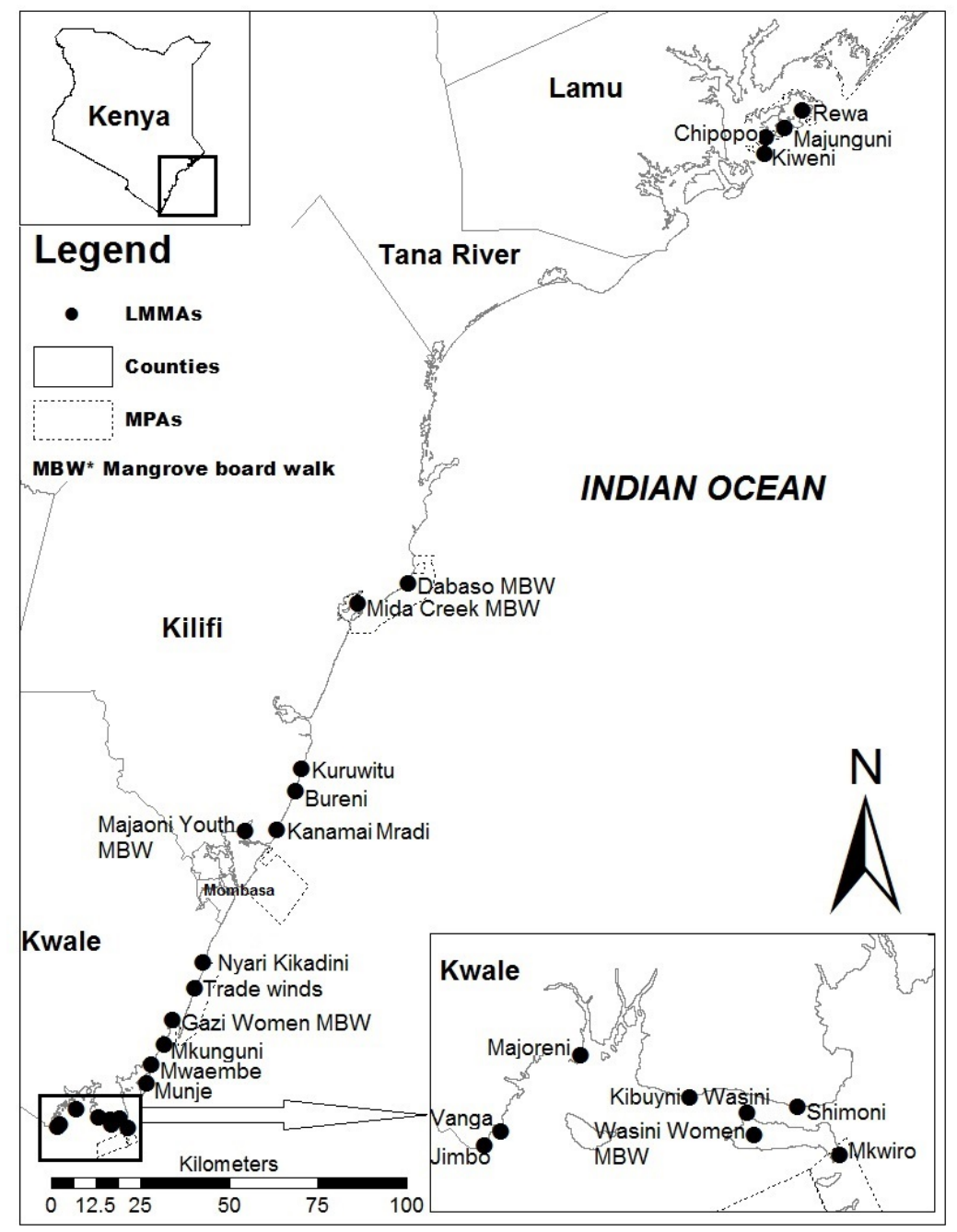

Source: Kawaka et al. 2015

Figure 12: Map showing the location of 24 LMMAs in Kenya, out of which 5 are mangrove boardwalks 
In recognizing the broad range of drivers, from poor education, to port development to overfishing, we believe there is a high risk in only investing in community-based conservation approaches. These recommendations therefore span higher-level policy efforts as well as community-driven initiatives and are all of equal importance. They include:

- Instigate full enforcement of existing regulations and policies so that marine biodiversity is managed properly. This requires effective enforcement of the Management Plan of the Kiunga Marine Reserve.

- Introduce marine spatial planning (MSP) approaches in Lamu County planning that includes resilience-based management of corals reefs (e.g. focused protection on most resilient reefs) and targeted conservation of high value, rare and endemic species.

- Improve management of mangrove forests so that harvesting is strictly sustainable.

- Conduct research on the integrity of the marine ecosystems to ensure the habitats are considered in zoning of community and government MPAs. There is need to research on the diverse fisheries in the pelagic environment to establish the threat and opportunities in the area.

- Conduct research on shark and ray species diversity and population status urgently. There is minimal information available in the Lamu-Kiunga area, and in Kenya generally.

- Encourage ongoing monitoring and research on key ecosystems particularly corals reefs so that future impacts of interventions are measured and understood.

- Improve compliance with international Conventions including reporting based on current science and status of resources, particularly to the CBD.

- Instigate full enforcement of existing regulations and policies so that fisheries are managed properly. This requires effective enforcement patrols and the removal of illegal fishing gears namely beach seines and monofilament gill nets.

- Introduce new fisheries legislation which address other destructive gears such as small mesh sizes of gill nets which capture juvenile fish; policies for minimizing bycatch of threatened species such as sharks, dolphins and turtles; and market-based research to promote fishing of large-sized fish.

- Ensure VMS (vessel monitoring systems) are in place, observers are on board, and licenses are correctly administered for foreign fishing vessels in EEZ waters to combat Illegal Unregulated and Unreported (IUU) fishing.

- Ensure a percentage of government income from licensed foreign fishing vessels is returned directly to Lamu County for visible benefits to fishing communities.

- Consider payment for ecosystem services (PES) charges to foreign fishing vessels that benefit from the good management of coastal mangrove systems that support productive offshore fishery stocks.

- Influence the development of the Lamu Port so that its construction is environmentally considerate and local communities are fully informed and involved in mitigation processes. 
- Increase government support to artisanal fishing communities to mitigate negative impacts from the development of the Lamu Port. Compensation due to foreseen loss of customary fishing grounds is needed.

- Protect mangroves to the south and north of the Manda channel (proposed port access) in order to maintain some of the ecological function and hence productivity of the natural ecosystem.

- Substantially improve access to education in all coastal communities in the Lamu-Kiunga area, with additional emphasis on girls who are traditionally neglected.

- Introduce long-term education programmes that address environmental management in all coastal communities for children and adults so the benefits of wise management to maximize ecosystem goods and services are embraced.

- Introduce other coastal enterprises with local communities to reduce pressure on marine resources.

- Empower fishing communities in co-management approaches to marine resource management (e.g. through BMUs) so that they can engage as equal players in managing their own fishery resources.

- Integrate local knowledge with government regulations, including in the Kiunga National Reserve, and science, to benefit the ecosystems and people of this unique part of Kenya's coast. 
Abuodha PAW, Kairo IG. 2001. Human-induced stresses on mangrove swamps along the Kenyan Coast. Hydrobiologia 458: 255-265.

Allen GR, Werner TB. 2002. Coral reef fish assessment in the coral triangle of southeastern Asia. Env. Biol. Fish. 65:209-214.

Alongi DM. 2002. Present state and future of the world's mangrove forests. Environmental Conservation, 29(03), 331-349.

Burns KA, Garrity SD, Jorissen D, MacPherson J, Stoelting M, Tierney J, Yelle-Simmons L. 1994. The Galeta oil spill; II, unexpected persistence of oil trapped in mangrove sediments. Estuarine, Coastal and Shelf Science 38 (4), 349-364.

Cande SC, Stegman DR. 2011. Indian and African plate motions driven by the push force of the Réunion plume head. Nature 475, pp. 47-52.

Carlton JM. 1974. Land building and stabilization by mangroves. Environmental Conservation, 1(04), 285-294.

Carpenter KE, Abrar M, Aeby G, Aronson RB, Banks S, Bruckner AM, Wood E. 2008. One-third of reefbuilding corals face elevated extinction risk from climate change and local impacts. Science, 321(5888), 560-563.

Church JE, Obura DO. 2003. Management recommendations for the Kiunga Marine National Reserve, based on coral reef and fisheries catch surveys, 1998-2003.

Church JE, Obura DO. 2004. Management recommendations for the Kiunga Marine National Reserve, based on coral reef and fisheries catch surveys, 1998-2003. CORDIO/WWF KMNR.57pp.

Church JE, Obura DO. 2006. Sustaining coral reef ecosystems and their fisheries in the Kiunga Marine National Reserve, Lamu, Kenya; Proceedings ofthe $10^{\text {th }}$ International Coral Reef Symposium 13811390.

Conservation International. 2008. Economic Values of Coral Reefs, Mangroves, and Seagrasses: A Global Compilation. Center for Applied Biodiversity Science, Conservation International, Arlington, VA, USA.

Dahdouh-Guebas F, Verneirt M, Cannicci S, Kairo JG, Tack JF, Koedam N. 2002. An exploratory study on grapsid crab zonation in Kenyan mangroves. Wetlands Ecology and Management, 10(3), 179-187. 
De La Cruz AA. 1979. The functions of mangroves. Proc. Biotrop. Spec. Pub, (10), 125-138.

Doute RN, Ochanda N, Epp H. 1981. A forest inventory of Kenya using remote sensing techniques. KREMU, Technical report series No. 30, Nairobi: Kenya Rangeland Ecological Monitoring Unit.

FAO, UNEP. 1981. Tropical forest resources assessment project, forest resources of tropical Africa. Part II: Country Briefs FAO, UNEP 586pp.

FAO. 1991. Report on brackish water/coastal aquaculture development. Based on the work of Tiensongrusmee, B. FO:TCP/KEN/0051 (A). Field document No.1. Rome, 41 pp.

FAO. 1993. Conservation and management of mangrove - Kenya. Terminal report FO:TCP/KEN/0051. FAO, Rome. 18 pp.

FAO. 2007. The World's Mangroves 1980-2005: A thematic study prepared in the framework of the Global Forest Resources Assessment 2005, FAO Forestry Paper-153.

Feller IC, Lovelock CE, Berger U, McKee KL, Joye SB, Ball MC. 2010. Biocomplexity in mangrove ecosystems. Annual Review of Marine Science, 2, 395-417.

Ferguson W. 1993. A landscape ecological survey of mangrove resource of Kenya. Kenya Wildlife Service and Forest Department, Nairobi (draft).

Forest Department, Kenya. 1983. Operational cruise on Lamu mangroves. Nairobi.

Gang PO. 1995. Application of remote sensing to determine the status of mangrove forest along the Kenyan coast. In: Proceedings of the Caring for the Forest: Research in a Changing World Conference,IUFRO-95, 6-12 August 1995, Tampere, Finland.

http://www.metla.fi/iufro/iufro95abs/d4pos18.htm

Govan $\mathrm{H}$ et al. 2009. Status and potential of locally-managed marine areas in the South Pacific: meeting nature conservation and sustainable livelihood targets through wide-spread implementation of LMMAs. SPREP/WWF/WorldFish-Reefbase/CRISP. 95pp + 5 annexes.

Government of Kenya. 1999. Environmental Management and Coordination's Act. Nairobi, Kenya: Government Press.

Government of Kenya. 2007. Fisheries (Beach Management Unit) Regulations. Nairobi, Kenya: Government Press.

Government of Kenya. 2009. Kenya state of the coast report: towards the integrated management of Kenya's coastal and marine resources. Nairobi: UNEP and NEMA. 
Government of Kenya. Rev. 2012. Fisheries Act (Cap 378). Nairobi, Kenya: Government Press.

Government of Kenya. 2012. Marine waters frame survey 2012 report. Ministry of Livestock and Fisheries Development, Fisheries Department, Nairobi (Kenya). 78 pp

Government of Kenya. Rev. 2012. Science and Technology Act (Cap 250). Nairobi, Kenya: Government Press.

Government of Kenya. 2013. Wildlife Conservation and Management Act. Nairobi, Kenya: Government Press.

Goreau T, McClanahan T, Hayes R, Strong AL. 2000. Conservation of coral reefs after the 1998 global bleaching event. Conservation Biology, 14(1), 5-15.

Grant DKS. 1938. Mangrove woods of Tanganyika Territory: Their silviculture and dependent industries. Tanganyika Notes and Records, 5: 5-16.

Halpern BS. 2003. The impact of marine reserves: Do reserves work and does reserve size matter? Ecol. Appl. 13:S117-S137.

Hamilton HGH, Brakel WH. 1984. Structure and coral fauna of East African reefs. Bull. Mar. Sci. 34: 248-266.

Harrison P, Samoilys M. 2009. Livelihood opportunities for coastal communities in Kiunga, Kenya: Prospects for livelihood diversification amid improved natural resources management in Kiunga Marine National Reserve. Kibodo/Kilimanyika/CORDIO Report.

IUCN. 2004. Managing marine protected areas: A toolkit for the Western Indian Ocean. IUCN Eastern Africa Regional Programme. Nairobi, Kenya.

Jennerjahn TC, Ittekkot V. 2002. Relevance of mangroves for the production and deposition of organic matter along tropical continental margins. Naturwissenschaften, 89(1), 23-30.

Kairo JG. 1995. Artificial regeneration and sustainable yield management of mangrove forests at Gazi bay, Kenya. MSc Thesis. University of Nairobi, Kenya.

Kairo JG. 2001. Ecology and restoration of mangrove systems in Kenya. PhD dissertation, Vrije Universiteit Brussel, Brussels, Belgium.

Kairo JG, Kivyatu B, Koedam N. 2002. Application of remote sensing and GIS in the management of mangrove forests within and adjacent to Kiunga Marine Protected Area, Lamu, Kenya. Environment, Development and Sustainability 4: 153-166. 
Kairo JG, Dahdouh-Guebas F. 2004. Conservation status of mangrove resources in Kenya. Review on Mangrove Conservation and Biodiversity (Draft).

Kathiresan K, Bingham BL. 2001. Biology of mangroves and mangrove ecosystems. Advances in Marine Biology 40: 81-251.

Kawaka J, Samoilys M, Murunga M, Church J, Abunge C, Maina GW. 2015. Locally Managed Marine Areas in Kenya: a detailed history of their development and establishment. CORDIO East Africa.

Kelleher G. 1999. Guidelines for marine protected areas. IUCN, Gland, Switzerland and Cambridge, UK. xxiv +107pp.

Kirui KB, Kairo JG, Bosire J, Viergever KM, Rudra S, Huxham M, Briers RA. 2011. Mapping of mangrove forest land cover change along the Kenya coastline using Landsat imagery. Ocean and Coastal Management, 83, 19-24.

Klekowski EJ, Corredor JE, Morell JM, Del Castillo CA. 1994. Petroleum pollution and mutation in mangroves. Marine Pollution Bulletin, 28(3), 166-169.

Lang'at JK, Kairo JG. 2013. Conservation and management of mangrove forests in Kenya.

Maina GW, Samoilys MA. 2011. Lamu lobsters - a dwindling resource. Swara 3: 34-35.

Maina GW, Osuka K, Samoilys M. 2011. Opportunities and challenges of community-based marine protected areas in Kenya. Mombasa, Kenya: FFI/CORDIO East Africa.

Maiti SK, Chowdhury A. 2013. Effects of anthropogenic pollution on mangrove biodiversity: A Review. Journal of Environmental Protection, 2013.

Mangi SC, Roberts CM. 2006. Quantifying the environmental impacts of artisanal fishing gear on Kenya's coral reef ecosystems. Marine Pollution Bulletin, 52(12), 1646-1660.

McClanahan TR. 1988. Seasonality in East Africa's coastal waters. Mar. Ecol. Prog. Ser. 44: 191-199.

McClanahan TR, Graham NAJ. 2005. Recovery trajectories of coral reef fish assemblages within Kenyan marine protected areas. Mar Ecol Prog Ser. Vol. 294: 241-248.

McClanahan TR, Ateweberhan M, Darling ES, Graham NAJ, Muthiga NA. 2014. Biogeography and change among regional coral communities across the Western Indian Ocean. PLOS ONE 9(4), e93385.

Nagelkerken I. 2009. Ecological connectivity among tropical coastal ecosystems. Netherlands: Springer. 
NEMA. 2013. Environmental impact assessment study report for construction of the first three berths of the proposed Lamu Port and Associated Infrastructure. Save Lamu

Obura DO. 2008. Scleractinian coral fauna of the Western Indian Ocean. In: Obura DO, Tamelander J, Linden $\mathrm{O}$ (eds) Ten years after bleaching - facing the consequences of climate change in the Indian Ocean. CORDIO Status Report 2008. CORDIO (Coastal Oceans Research and Development in the Indian Ocean)/Sida-SAREC. Mombasa. 139-147 pp.

Obura D. 2012. The diversity and biogeography of Western Indian Ocean reef-building corals. PloS One. 7.

Obura DO, Church J, Mwadzaya H, Wekesa E, Muthiga NA. 1998. Rapid assessment of coral reef biophysical and socioeconomic conditions in the Kiunga Marine Reserve, Kenya: Methods Development and Evaluation. FAO/UNEP.

Obura DO, Church JE. 2004. Coral reef monitoring in the Kiunga Marine Reserve, Kenya. 1998-2003, CORDIO East Africa/WWF East Africa Regional Programme Office.

Obura D, Amiyo N, Olendo M, Visram S. 2007. Coral reef monitoring update, 2004-6. Kiunga Marine National Reserve, Kenya. CORDIO East Africa/WWF East Africa Regional Programme Office/Kenya Wildlife Service.

Obura DO, Church JE, Gabrié C. 2012. Assessing Marine World Heritage from an Ecosystem Perspective: The Western Indian Ocean. World Heritage Centre, United Nations Education, Science and Cultural Organization (UNESCO). 124 pp.

Ochiewo J, Kimani E, Okemwa G, Onganda H. 2009. The management capacity and socio-economic characteristics of the fisher communities in Lamu Seascape. Technical report. WWF-EARPO Marine Programme for Kenya. Project number-KE086701. Agreement number FY09/EAME/05.

Okello JA, Osuka K, Mbugua J, Maina GW, Samoilys MA. 2015. Survey of the mangroves of KiungaPate Island for baseline biodiversity data. CORDIO/TNC/KMFRI Report. 28pp.

Pandolfi JM, Bradbury RH, Sala E, Hughes TP, Bjorndal BA, Cooke GR, McArdle D, McClenachan L, Newman MJH, Paredes G, Warner RR, Jackson JBC. 2003. Global Trajectories of the Long Term Decline of Coral Reef Ecosystems, American Association for the Advancement of Science, vol. 301 no. 5635 955-958, DOI: http://dx.doi.org/10.1126/science.1085706

Pandolfi JM, Connolly SR, Marshall DJ, Cohen AL. 2011. Projecting coral reef futures under global warming and ocean acidification. Science, 333(6041), 418-422. 
Pepper JF, Everhart GM. 1963. The Indian Ocean. The geology of its bordering lands and the configuration of its floor. Booklet accompanying map, 1-380.

Rawlins SP. 1957. The East African mangrove trade. Unpublished manuscript \#51 of the National Museum of Kenya, Nairobi, Kenya.

Ricklefs RE, Latham RE. 1993. Global patterns of diversity in mangrove floras. In: Ricklefs RE, Schluter D (eds) Species diversity in ecological communities. Historical and geographical perspectives. University of Chicago Press, Chicago: 215-233.

Roberts RW, Ruara WW. 1967. Lamu Mangrove Inventory. Forest Department, Nairobi, Kenya.

Rogers AD, Sumaila UR, Hussain SS, Baulcomb C. 2014. The High Seas and Us: Understanding the Value of High-Seas Ecosystems. Global Ocean Commission.

Rosen BR. 1971. The distribution of reef coral genera in the Indian Ocean.

Russ GR. 2002. Yet another review of marine reserves as reef fishery management tools. In: Sale PF (ed) Coral reef fishes: dynamics and diversity in a complex ecosystem. Academic Press, San Diego, California, USA, 421-443.

Schott FA, Xie S-P, McCreary Jr JP. 2009, Indian Ocean circulation and climate variability, Rev. Geophys., 47, RG1002, doi: 10.1029/2007RG000245.

Samoilys MA. 1988. Abundance and species richness of coral reef fishes on the Kenyan coast: the effects of protective management and fishing. Proc. 6 ' international Conference. Townsville, Australia, Coral Reefs symposium, 2, 261-266.

Samoilys M, Carlos G. 2000. Determining methods of underwater visual census for estimating the abundance of coral reef fishes. Environmental Biology of Fishes 57(3):289-304

Samoilys MA, Kanyange NW. 2008. Natural resource dependence, livelihoods and development: perceptions from Kiunga, Kenya. IUCN/CORDIO/KNCF/IDRC. 28 pp.

Samoilys M, Randriamanantsoa B. 2011. Reef fishes of Northeast Madagascar. In: Obura D, Di Carlo G, Rabearisoa A, Oliver T (eds) A rapid marine biodiversity assessment of the coral reefs of northeast Madagascar. Conservation International/ CORDIO/John D and Catherine T Macarthur Foundation.

Samoilys MA, Obura DO. 2011 Conservation successes in the Western Indian Ocean. In: Obura DO, Samoilys MA (Eds) CORDIO Status Report 2011. CORDIO East Africa. 
Samoilys MA, Osuka K, Maina G. 2011a. Review and assessment of biodiversity values and conservation priorities along the Tana Delta- Pate Island coast of Kenya. In: Obura DO, Samoilys MA (Eds) CORDIO Status Report 2011. CORDIO East Africa.

Samoilys MA, Maina GW, Osuka K. 2011b. Artisanal fishing gears of the Kenyan Coast. Mombasa CORDIO/USAID.

Samoilys MA, Osuka K,Maina GW. 2011c. Opportunities and challenges of current legislation for effective conservation in the Tana Delta - Pate Island region of the Kenyan coast. In: Obura DO, Samoilys MA (Eds) 2011. CORDIO Status Report 2011. CORDIO East Africa.

Samoilys MA, Alvarez Filip L. 2012. Patterns in the diversity of reef fishes in the Western Indian Ocean. $10^{\text {th }}$ ICRS: Conference presentation, Cairns.

Samoilys M, Pabari M, Andrew T, Maina GW, Church J, MomanyiA, MibeiB, Monjane M, Shah A, Menomussangab M, Muttad D. 2015. Resilience of coastal systems and their human partners: ecological and social profile of coastal systems in Kenya, Mozambique and Tanzania. Nairobi, Kenya: IUCN ESARO, WIOMSA, CORDIO and UNEP Nairobi Convention, $x+74 p p$.

Samoilys MA, Osuka K, Maina G, Obura D. (in press). Reaching the limits of artisanal fishing on the Kenyan coast? Fisheries Research.

Semesi AK. 1992. The coastal system of East Africa Mangrove Ecosystem study. Proceedings of the COMAR Interregional Scientific Conference UNESCO, Paris, 21-25 May 1991. UNESCO technical papers in marine science 64, UNESCO.

Smith TJ. 1992. Forest structure. In: Robertson Al, Alongi DM (eds)xTropical Mangrove Ecosystems, pp. 101-136. Washington DC, USA: American Geophysical Union.

Spalding M, Blasco F, Field C. 1997. World mangrove atlas. Okinawa, Japan: The International Society for Mangrove Ecosystems: 178 pp.

Spalding MD, Kainuma M, Collins L. 2010World atlas of mangroves. Earthscan. 319 pp.

Survey of Kenya. 2009. Republic of Kenya's outer limit of the continental shelf beyond 200m. Kenya Government.

http://www.un.org/depts/los/clcs_new/submissions_files/ken35_09/ken2009_map1.pdf

Terrados J, Borum J. 2004. Why are seagrasses important? Goods and services provided by seagrass meadows. European seagrasses: an introduction to monitoring and management, 8-10. 
[UNEP] United Nations Environment Programme. 2009. Transboundary diagnostic analysis of landbased sources and activities affecting the western Indian Ocean coastal and marine environment. UNEP/Nairobi Convention Secretariat, Nairobi, Kenya. 378 pp.

Van Speybroeck D. 1992. Regeneration strategy of mangroves along the Kenya coast: a first approach. In: The Ecology of Mangrove and Related Ecosystems (pp. 243-251). Springer Netherlands.

Van der Elst RP, Everett BI (eds) 2015. Offshore fisheries of the Southwest Indian Ocean: their status and the impact on vulnerable species. Oceanographic Research Institute, Special Publication, 10. $448 \mathrm{pp}$.

Valerie R. 2014. Analyzing the dynamics of the artisan fishing industry and LAPSSET port in Lamu, Kenya. Independent Study Project (ISP) Collection. Paper 1765.

http://digitalcollections.sit.edu/isp_collection/1765

Wamukoya GM, Mirangi JM, Ottichillo WK, Cockcroft V, Salm R. 1996. Report on the marine aerial survey of marine mammals, sea turtles, sharks and rays.

Wanyonyi I, Crona B, Rosendo S. 2011. Migrant fishers and fishing in the Western Indian Ocean: socioeconomic dynamics and implications for management. Final Report of Commissioned Research Project MASMA/CR/2008/02.

Weru SM, Church J, Lubia L, Nekesa N, Verheij E, Koyo AO, Muthiga N, Kavu BK, Kareko JK, Litoro M. 2001. Management Plan Kiunga Marine National Park and Reserve.

West JM, Salm RV. 2003. Resistance and resilience to coral bleaching: implications for coral reef conservation and management. Conservation Biology, 17(4), 956-967.

World Resources Institute. 2000. World resources 2000-2001: people and ecosystem - the fraying web of life. Washington, DC. UNDP. 400 pp.

WRI, UNEP, UNDP, The World Bank. 1996. World Resources 1996-1997. New York and Oxford University Press 365 pp.

WWF. 1996. Conservation and development of the Kiunga Marine Reserve area Kenya. WWF. 
Appendix 1. Coral genera and species list recorded in Pate-Kiunga 2015

\section{Coral Genera}

1. Acanthastrea

2. Acropora

3. Alveopora

4. Astreopora

5. Caulastrea

6. Coeloseris

7. Coscinaraea

8. Craterastrea

9. Cycloseris

10. Cyphastrea

11. Echinophyllia

12. Echinopora

13. Favia

14. Favites

15. Fungia

16. Galaxea

17. Gardineroseris

18. Goniastrea

19. Goniopora

20. Heliopora

21. Herpolitha

22. Homophyllia

23. Horastrea

24. Hydnopohora

25. Leptastrea

26. Leptoria

27. Leptoseris

28. Lobophyllia

29. Micromussa

30. Millepora

31. Montipora

32. Oulophyllia

33. Pavona

34. Platygyra

35. Plesiastrea

36. Pocillopora

37. Porites

38. Psammocora

39. Pseudosiderastrea

40. Scolymia

41. Siderastrea

42. Tubastrea

43. Tubipora

44. Turbinaria 


\section{Coral species}

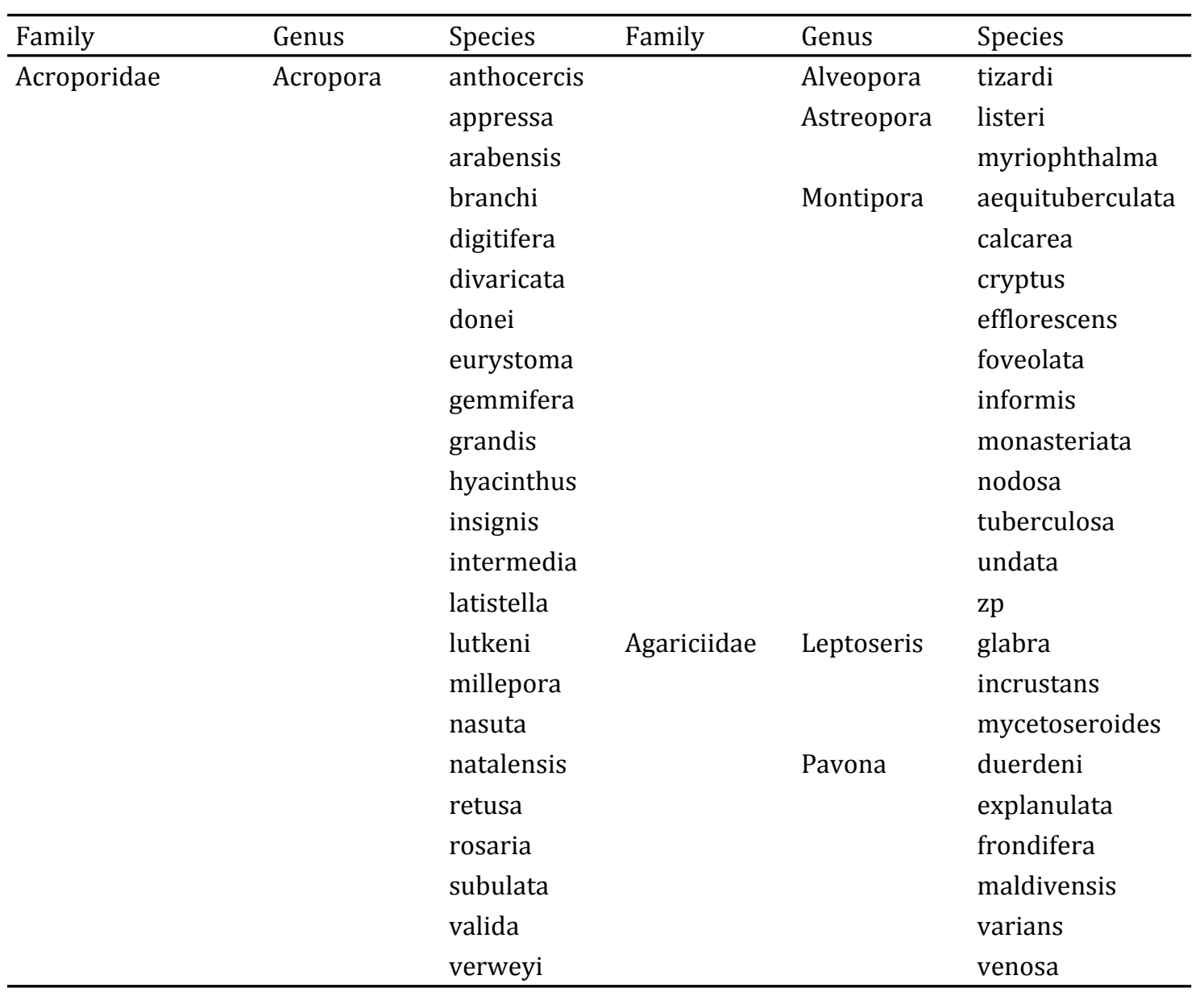




\begin{tabular}{|c|c|c|c|c|c|}
\hline Family & Genus & Species & Family & Genus & Species \\
\hline \multirow[t]{6}{*}{ Coscinaraeidae } & Coscinaraea & columna & & Favites & abdita \\
\hline & & crassa & & & acuticolis \\
\hline & & exesa & & & complanata \\
\hline & & monile & & & flexuosa \\
\hline & & $\mathrm{zpA}$ & & & halicora \\
\hline & Horastrea & indica & & & pentagona \\
\hline \multirow[t]{4}{*}{ Dendrophylliidae } & Tubastrea & zpp & & & russelli \\
\hline & Turbinaria & mesenterina & & & vasta \\
\hline & & peltata & & Goniastrea & australensis \\
\hline & & stellulata & & & columella \\
\hline \multirow[t]{19}{*}{ Faviidae } & Caulastrea & connata & & & deformis \\
\hline & Cyphastrea & chalcidicum & & & edwardsi \\
\hline & & serailia & & & palauensis \\
\hline & Echinopora & gemmacea & & & peresi \\
\hline & & hirsutissima & & & retiformis \\
\hline & & lamellosa & & Leptastrea & aequalis \\
\hline & & pacificus & & & pruinosa \\
\hline & & robusta & & & purpurea \\
\hline & Favia & danae & & Leptoria & phrygia \\
\hline & & favus & & Oulophyllia & crispa \\
\hline & & helianthoides & & Platygyra & acuta \\
\hline & & lizardensis & & & contorta \\
\hline & & maritima & & & crosslandi \\
\hline & & matthai & & & daedalea \\
\hline & & pallida & & & pini \\
\hline & & rotumana & & & sinensis \\
\hline & & speciosa & & & verweyi \\
\hline & & stelligera & & Plesiastrea & devantieri \\
\hline & & truncatus & & & versipora \\
\hline
\end{tabular}




\begin{tabular}{|c|c|c|c|c|c|}
\hline Family & Genus & Species & Family & Genus & Species \\
\hline \multirow[t]{12}{*}{ Fungiidae } & Cycloseris & costulata & Pectiniidae & Echinophyllia & aspera \\
\hline & & cyclolytes & & & echinata \\
\hline & & explanulata & Pocilloporidae & Pocillopora & damicornis \\
\hline & & patelliformis & & & eydouxi \\
\hline & & wellsi & & & indiania \\
\hline & Diaseris & fragilis & & & ligulata \\
\hline & Fungia & granulosa & & & verrucosa \\
\hline & & paumotensis & Poritidae & Goniopora & albiconus \\
\hline & & repanda & & & columna \\
\hline & & scutaria & & & djiboutiensis \\
\hline & Herpolitha & $\operatorname{limax}$ & & & lobata \\
\hline & & weberi & & & planulata \\
\hline \multirow[t]{3}{*}{ Hydrozoa } & Heliopora & coerulea & & & somaliensis \\
\hline & Millepora & exesa & & & stokesi \\
\hline & & platyphylla & & & zp. \\
\hline \multirow[t]{2}{*}{ Merulinidae } & Hydnophora & exesa & & Porites & annae \\
\hline & & pilosa & & & Columnaris \\
\hline \multirow[t]{9}{*}{ Mussidae } & Acanthastrea & echinata & & & cylindrica \\
\hline & & hemprichii & & & harrisoni \\
\hline & & regularis & & & lobata \\
\hline & Homophyllia & australis & & & lutea \\
\hline & Lobophyllia & corymbosa & & & nodifera \\
\hline & & hemprichii & & & rus \\
\hline & & robusta & & & stephensoni \\
\hline & Micromussa & indiana & Siderastreidae & Psammocora & contigua \\
\hline & Sclerophyllia & maxima & & Pseudosiderastrea & tayami \\
\hline \multirow[t]{2}{*}{ Oculinidae } & Galaxea & astreata & & Siderastrea & savignyana \\
\hline & & fasicularis & & & \\
\hline
\end{tabular}




\section{Appendix 2. Data treatment and analysis}

Methods

Sites were selected based on the years of monitoring; those monitored for more than 7 years (Table 111).

Sites used in analysis of coral reef health in Kiunga-Pate area

\begin{tabular}{|c|c|c|c|}
\hline Block & Selected sites & $\begin{array}{l}\text { Samoilys et al. } \\
1987 \text { sites } \\
\text { (distance) }\end{array}$ & Reasons \\
\hline Ishakani & Shili & & Surveyed for 8 years \\
\hline \multirow[t]{8}{*}{ Kiunga } & Bomani & & Surveyed for 9 years \\
\hline & Ch. Boso & & Surveyed for 7 years \\
\hline & Boso & & Surveyed for 10 years \\
\hline & Kijiweni & & Surveyed for 9 years \\
\hline & Kishanga & & Surveyed for 9 years \\
\hline & Kui & & Surveyed for 10 years \\
\hline & Kupi & & Surveyed for 8 years \\
\hline & Mw. Mkuu & & Surveyed for 10 years \\
\hline \multirow{7}{*}{ Kiwayu } & & Kiwayu Knolls & \\
\hline & Ch. Chano & $(7,000 \mathrm{~m})$ & Surveyed in 1987 and later continuously surveyed for 10 yea \\
\hline & Mike's Inner & & Surveyed for 10 years \\
\hline & Mike's outer & & Surveyed for 9 years \\
\hline & Mkokoni_Coral & & \\
\hline & Garden & & Surveyed for 9 years \\
\hline & Shimo la Tewa & & Surveyed for 9 years \\
\hline \multirow[t]{3}{*}{ Mkokoni } & Ch. Mvundeni & Arlett $(2,200 \mathrm{~m})$ & Surveyed in 1987 and later continuously surveyed for 2 years \\
\hline & Kwa Radi & & Surveyed for 10 years \\
\hline & Ml. Hindi & & Surveyed for 8 years \\
\hline \multirow{4}{*}{ Rubu } & & Simbaya Ledge & \\
\hline & Ch. magogoni & $(1,000 \mathrm{~m})$ & \\
\hline & Ch. Mongo Shariff & & Surveyed for 7 years \\
\hline & Chole & & Surveyed for 10 years \\
\hline \multirow[t]{2}{*}{ Pethali } & Iweni & & Surveyed for 3 years \\
\hline & Pezali Rock & & Surveyed for 4 years \\
\hline Lamu & Kinyika & Kinyika $(1,700 \mathrm{~m})$ & Surveyed in 1987 and later continuously survey \\
\hline
\end{tabular}

Analysis

Data were analysed by first detecting outliers on the annual data of 11 fish families using Grubbs test and thereafter removing the outliers. The sites were then categorized into management blocks as presented in Table 111. The density data were log $(x+1)$ transformed before running a one-way ANOVA test to compare the years and management blocks. 


\section{Appendix 3. Fish species list recorded in Pate-Kiunga in 2015}

Colour coded families are the 5 families used to calculate the CFDI diversity index.

\begin{tabular}{|c|c|}
\hline Family & Species \\
\hline Pomacentridae & A. sexfasciatus \\
\hline Pomacentridae & A. sparoides \\
\hline Pomacentridae & A. vaigiensis \\
\hline Pomacentridae & Amblygl. indicus \\
\hline Pomacentridae & Amphiprion akallopisos \\
\hline Pomacentridae & C. atripectoralis \\
\hline Pomacentridae & C. dimidiata \\
\hline Pomacentridae & C. lepidolepis \\
\hline Pomacentridae & C. ternatensis \\
\hline Pomacentridae & C. viridis \\
\hline Pomacentridae & C. weberi \\
\hline Pomacentridae & Chry. biocellata \\
\hline Pomacentridae & Chry. brownriggii \\
\hline Pomacentridae & D. trimaculatus \\
\hline Pomacentridae & D.carneus \\
\hline Pomacentridae & Dascylus aruanus \\
\hline Pomacentridae & N. cyanomos \\
\hline Pomacentridae & Neoglyphid. melas \\
\hline Pomacentridae & Neopom. azysron \\
\hline Pomacentridae & Neopom. sp.1 \\
\hline Pomacentridae & P. baenschi \\
\hline Pomacentridae & P. caeruleus \\
\hline Pomacentridae & P. pavo \\
\hline Pomacentridae & P. sulfureus \\
\hline Pomacentridae & P. trilineatus \\
\hline Pomacentridae & Pl. lacrymatus \\
\hline Pomacentridae & Plectroglyphid. dickii \\
\hline Pomacentridae & Pomacentrus caeruleopunctatus \\
\hline Pomacentridae & Pomacentrus sp.2 \\
\hline Pomacentridae & S. nigricans \\
\hline Pomacanthidae & C. multispinis \\
\hline Pomacanthidae & P. imperator \\
\hline Pomacanthidae & P. semicirculatus \\
\hline Pomacanthidae & Pomacanthus chrysurus \\
\hline Labridae & A. melanurus \\
\hline Labridae & A. twistii \\
\hline Labridae & An. lineatus \\
\hline Labridae & B. axillaris \\
\hline
\end{tabular}




\begin{tabular}{|c|c|}
\hline Labridae & B. bilunulatus \\
\hline Labridae & B. diana \\
\hline Labridae & C. caudimacula \\
\hline Labridae & C. freiri \\
\hline Labridae & C. oxycephalus \\
\hline Labridae & C. trilobatus \\
\hline Labridae & C. undulatus \\
\hline Labridae & Cheilinus bimaculatus \\
\hline Labridae & Cheilinus chlorourus \\
\hline Labridae & Cirrhilabrus exquisitus \\
\hline Labridae & Coris aygula \\
\hline Labridae & Epibulus insidiator \\
\hline Labridae & Gomphosus caeruleus \\
\hline Labridae & H. hortulanus \\
\hline Labridae & H. iridis \\
\hline Labridae & Halichoeres marginatus \\
\hline Labridae & H. nebulosus \\
\hline Labridae & H. scapularis \\
\hline Labridae & H. zeylonicus \\
\hline Labridae & Halichoeres cosmetus \\
\hline Labridae & L. dimidiatus \\
\hline Labridae & Labrichthys unilineatus \\
\hline Labridae & Labroides bicolor \\
\hline Labridae & Macropharyngodon bipartitus \\
\hline Labridae & Oxycheilinus digrammus \\
\hline Labridae & Oxycheilinus mentalis \\
\hline Labridae & Pseudocheilinus evanidus \\
\hline Labridae & Pseudocheilinus hexataenia \\
\hline Labridae & Pseudodax moluccanus \\
\hline Labridae & S. bandanensis \\
\hline Labridae & T. hardwicki \\
\hline Labridae & T. herbracium \\
\hline Labridae & T. lunare \\
\hline Labridae & Thalassoma lutescens \\
\hline Labridae & Thalassoma amblycephal \\
\hline Labridae & Thalassoma sp.1 -genivittatum? \\
\hline Chaetodontidae & C. bennetti \\
\hline Chaetodontidae & C. falcula \\
\hline Chaetodontidae & C. guttatissimus \\
\hline Chaetodontidae & C. interruptus \\
\hline Chaetodontidae & C. kleinii \\
\hline Chaetodontidae & C. leucopleura \\
\hline Chaetodontidae & C. lineolatus \\
\hline
\end{tabular}




\begin{tabular}{|c|c|}
\hline Chaetodontidae & C. Iunula \\
\hline Chaetodontidae & C. madagaskariensis \\
\hline Chaetodontidae & C. melannotus \\
\hline Chaetodontidae & C. meyeri \\
\hline Chaetodontidae & C. trifasciatus \\
\hline Chaetodontidae & C. xanthocephalus \\
\hline Chaetodontidae & Chaetodon auriga \\
\hline Chaetodontidae & F. longirostris \\
\hline Chaetodontidae & Heniochus acuminatus \\
\hline Chaetodontidae & Heniochus monoceros \\
\hline Scaridae & Calotomus carolinus \\
\hline Scaridae & Chlor. sordidus \\
\hline Scaridae & Chlor. atrilunula \\
\hline Scaridae & Hipposcarus harid \\
\hline Scaridae & S. frenatus \\
\hline Scaridae & S. ghobban \\
\hline Scaridae & S. niger \\
\hline Scaridae & S. rubroviolaceus \\
\hline Scaridae & S. russelli \\
\hline Acanthuridae & A. blochii \\
\hline Acanthuridae & A. dussumieri \\
\hline Acanthuridae & A. leucocheilus \\
\hline Acanthuridae & A. leucosternon \\
\hline Acanthuridae & A. lineatus \\
\hline Acanthuridae & A. mata \\
\hline Acanthuridae & A. nigricaudus \\
\hline Acanthuridae & A. nigrofuscus \\
\hline Acanthuridae & A. tennenti \\
\hline Acanthuridae & A. triostegus \\
\hline Acanthuridae & A. xanthopterus \\
\hline Acanthuridae & C. striatus \\
\hline Acanthuridae & C. truncatus \\
\hline Acanthuridae & Ctenochaetus binot \\
\hline Acanthuridae & N. brachycentron \\
\hline Acanthuridae & N. brevirostris \\
\hline Acanthuridae & N. elegans \\
\hline Acanthuridae & N. unicornis \\
\hline Acanthuridae & Naso annulatus \\
\hline Acanthuridae & Paracanth. hepatus \\
\hline Acanthuridae & Z. vellifer \\
\hline Acanthuridae & Zebrasom. desjardinii \\
\hline Balistidae & Balistapus undulatus \\
\hline Balistidae & Balistoid. conspicillum \\
\hline
\end{tabular}




\begin{tabular}{|c|c|}
\hline Balistidae & Melichthys indicus \\
\hline Balistidae & Melichthys niger \\
\hline Balistidae & Odonus niger \\
\hline Balistidae & P. fuscus \\
\hline Balistidae & Rhinecanth. aculeatus \\
\hline Balistidae & S. chrysopterum \\
\hline Balistidae & S. fraenatus \\
\hline Balistidae & Sufflamen bursa \\
\hline Caesionidae & C. Iunaris \\
\hline Caesionidae & C. xanthonota \\
\hline Caesionidae & Caesio caerulaurea \\
\hline Caesionidae & Caesio teres \\
\hline Caesionidae & Pterocaesio marri \\
\hline Caesionidae & Pterocaesio pisang \\
\hline Caesionidae & Pterocaesio sp. (cf trilineata) \\
\hline Carangidae & C. ferdau \\
\hline Carangidae & C. fulvoguttatus \\
\hline Carangidae & C. sexfasciatus \\
\hline Carangidae & S. Iysan \\
\hline Carangidae & Carangoid. sp1 \\
\hline Haemulidae & Diagramma picta \\
\hline Haemulidae & P. gaterinus \\
\hline Haemulidae & P. gibbosus \\
\hline Haemulidae & P. plagiodesmus \\
\hline Haemulidae & P. playfairi \\
\hline Haemulidae & P. schotaf \\
\hline Haemulidae & Plectorhinchus albovittatus \\
\hline Haemulidae & Plectorhinchus flavomac. \\
\hline Haemulidae & Plectorhinchus sordidus \\
\hline Lethrinidae & L. harak \\
\hline Lethrinidae & L. obsoletus \\
\hline Lethrinidae & Monotaxis grandoc \\
\hline Lutjanidae & L. bohar \\
\hline Lutjanidae & L. ehrenbergi \\
\hline Lutjanidae & L. fulviflamma \\
\hline Lutjanidae & L. fulvus \\
\hline Lutjanidae & L. gibbus \\
\hline Lutjanidae & L. monostigma \\
\hline Lutjanidae & Lutjanus argentimac. \\
\hline Monacanthidae & Pervagor janthinosoma \\
\hline Mullidae & Mulloidi. flavolineatus \\
\hline Mullidae & P. cyclostomus \\
\hline Mullidae & P. indicus \\
\hline
\end{tabular}


Mullidae

Mullidae

Mullidae

Nemipteridae

Ostraciidae

Ostraciidae

Serranidae

Serranidae

Serranidae

Serranidae

Serranidae

Serranidae

Serranidae

Serranidae

Siganidae

Siganidae

Siganidae

Siganidae

Tetraodontidae

Tetraodontidae

Tetraodontidae

Tetraodontidae

Total
P. macronema

$P$. rubescens

Parupeneus barberinus

S. ghanam

O. meleagris

Ostracion cubicus

C. leopardus

Cephalopholis argus

Dermatolepis striolatus

E. caeruleopunctatus

E. fuscoguttatus

E. lanceolatus

E. malabaricus

Plectropomus laevis

S. luridus

S. stellatus

S. sutor

Siganus argenteus

C. valentini

Canthigaster bennetti

Canthigaster petersii

Canthigaster smithae

189 
221. Farmer-to-farmer extension of livestock feed technologies in Rwanda: A survey of volunteer farmer trainers and organizations http://dx.doi.org/10.5716/WP16005.PDF

222. Projected climate change impact on hydrology, bioclimatic conditions, and terrestrial ecosystems in the Asian highlands http://dx.doi.org/10.5716/WP16006.PDF

223. Adoption of agroforestry and its impact on household food security among farmers in Malawi http://dx.doi.org/10.5716/WP16013.PDF

224. Agroforestry and forestry in Sulawesi series: Information channels for disseminating innovative agroforestry practices to villages in Southern Sulawesi, Indonesia http://dx.doi.org/10.5716/WP16034.PDF

225. Agroforestry and forestry in Sulawesi series: Unravelling rural migration networks. Land-tenure arrangements among Bugis migrant communities in Southeast Sulawesi http://dx.doi.org/10.5716/WP16035.PDF

226. Agroforestry and forestry in Sulawesi series: Women's participation in agroforestry: more benefit or burden? A gendered analysis of Gorontalo Province http://dx.doi.org/10.5716/WP16036.PDF

227. Kajian Kelayakan dan Pengembangan Desain Teknis Rehabilitasi Pesisir di Sulawesi Tengah http://dx.doi.org/10.5716/WP16037.PDF

228. Selection of son tra clones in North West Vietnam http://dx.doi.org/10.5716/WP16038.PDF

229. Growth and fruit yield of seedlings, cuttings and grafts from selected son tra trees in Northwest Vietnam http://dx.doi.org/10.5716/WP16046.PDF

230. Gender-Focused Analysis of Poverty and Vulnerability in Yunnan, China http://dx.doi.org/10.5716/WP16071.PDF

231. Seri Agroforestri dan Kehutanan di Sulawesi: Kebutuhan Penyuluhan Agroforestri untuk Rehabilitasi Lahan di Sumba Timur, Nusa Tenggara Timur, Indonesia http://dx.doi.org/10.5716/WP16077.PDF

232. Agroforestry and Forestry in Sulawesi series: Agroforestry extension needs for land rehabilitation in East Sumba, East Nusa Tenggara, Indonesia. http://dx.doi.org/10.5716/WP16078.PDF

233. Central hypotheses for the third agroforestry paradigm within a common definition. http://dx.doi.org/10.5716/WP16079.PDF

234. Assessing smallholder farmers' interest in shade coffee trees: the farming systems of smallholder coffee producers in Gisenyi Area, Rwanda http://dx.doi.org/10.5716/WP16104.PDF

235. Review of agricultural market information systems in sub-Saharan Africa. DOI: http://dx.doi.org/10.5716/WP16110.PDF

236. Vision and road map for establishment of a protected area in Lag Badana, Lower Jubba, Somalia. DOI: http://dx.doi.org/10.5716/WP16127.PDF

237. Replicable tools and frameworks for Bio-Carbon Development in West Africa. http://dx.doi.org/10.5716/WP16138.PDF

238. Existing Conditions, Challenges and Needs in the Implementation of Forestry and Agroforestry Extension in Indonesia. http://dx.doi.org/10.5716/WP16141.PDF

239. Situasi Terkini, Tantangan dan Kebutuhan Pelaksanaan Penyuluhan Kehutanan dan Agroforestri di Indonesia. http://dx.doi.org/10.5716/WP16142.PDF

240. The national agroforestry policy of India:experiential learning in development and delivery phases. http://dx.doi.org/10.5716/WP16143.PDF

241. Agroforestry and Forestry in Sulawesi series: Livelihood strategies and land-use system dynamics in Gorontalo. http://dx.doi.org/10.5716/WP16157.PDF

242. Seri Agroforestri dan Kehutanan di Sulawesi: Strategi mata pencaharian dan dinamika sistem penggunaan lahan di Gorontalo. http://dx.doi.org/10.5716/WP16158.PDF

243. Ruang, Gender dan Kualitas Hidup Manusia: Sebuah studi Gender pada komunitas perantau dan pengelola kebun di Jawa Barat. http://dx.doi.org/10.5716/WP16159.PDF

244. Gendered knowledge and perception in managing grassland areas in East Sumba, Indonesia. http://dx.doi.org/10.5716/WP16160.PDF

245. Pengetahuan dan persepsi masyarakat pengelola padang aavana, Sebuah Kajian Gender di Sumba Timur. http://dx.doi.org/10.5716/WP16161.PDF

246. Dinamika Pengambilan Keputusan pada komunitas perantau dan pengelola kebun di Jawa Barat. http://dx.doi.org/10.5716/WP16162.PDF

247. Gaharu (eaglewood) domestication: Biotechnology, markets and agroforestry options. http://dx.doi.org/10.5716/WP16163.PDF 
The World Agroforestry Centre is an autonomous, non-profit research organization whose vision is a rural transformation in the developing world as smallholder households increase their use of trees in agricultural landscapes to improve food security, nutrition, income, health, shelter, social cohesion, energy resources and environmental sustainability. The Centre generates science-based knowledge about the diverse roles that trees play in agricultural landscapes, and uses its research to advance policies and practices, and their implementation that benefit the poor and the environment. It aims to ensure that all this is achieved by enhancing the quality of its science work, increasing operational efficiency, building and maintaining strong partnerships, accelerating the use and impact of its research, and promoting greater cohesion, interdependence and alignment within the organization.

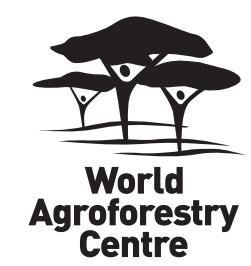

United Nations Avenue, Gigiri • PO Box 30677 • Nairobi, $00100 \cdot$ Kenya Telephone: +254207224000 or via USA +1 6508336645 Fax: +254207224001 or via USA +1 6508336646 Email: worldagroforestry@cgiar.org •www.worldagroforestry.org 